Check for updates

Cite this: RSC Adv., 2018, 8, 35625

\title{
Theoretical and experimental investigation of anticancer activities of an acyclic and symmetrical compartmental Schiff base ligand and its Co(II), $\mathrm{Cu}(\mathrm{II})$ and $\mathrm{Zn}(\mathrm{II})$ complexes $\uparrow$
}

\author{
Lotfali Saghatforoush, (DD *a Keyvan Moeini, (D) a Seyed Abolfazl Hosseini-Yazdi, ${ }^{\text {b }}$ \\ Zahra Mardani, (D) ${ }^{c}$ Alireza Hajabbas-Farshchi, (D) ${ }^{\mathrm{d}}$ Heather T. Jameson, ${ }^{\mathrm{e}}$ \\ Shane G. Telfer (D) ${ }^{\mathrm{e}}$ and J. Derek Woollins ${ }^{f}$
}

\begin{abstract}
A compartmental Schiff base ligand, 2,2'-((((((2-hydroxypropane-1,3-diyl)bis(oxy))bis(2,1-phenylene)) bis(methylene))bis(azanylylidene))bis(methanylylidene))bis(4-bromophenol) $\left(\mathrm{H}_{3} \mathrm{~L}^{\mathrm{Br}}\right.$ ) and its complexes with cobalt(॥), copper(॥) and zinc(॥) including, $\left[\mathrm{Co}\left(\mathrm{HL}^{\mathrm{Br}}\right)\right](1),\left[\mathrm{Cu}_{2}\left(\mathrm{~L}^{\mathrm{Br}}\right)(\mu-1,3-\mathrm{OAc})\right] \cdot \mathrm{MeOH}(2)$ and $\left[\mathrm{Zn}\left(\mathrm{HL}^{\mathrm{Br}}\right)\right](3)$ were prepared using template synthesis and characterised by elemental analysis, FT-IR and ${ }^{1} \mathrm{H} N M R$ spectroscopies and single-crystal X-ray diffraction. In the structure of complexes 1 and 3 the metal atom has a $\mathrm{MN}_{2} \mathrm{O}_{2}$ environment with tetrahedral geometry while complex 2 has a binuclear structure with a $\mathrm{MNO}_{4}$ environment and square planar geometry around the copper atom. The ability of all compounds to interact with the nine biomacromolecules (BRAF kinase, CatB, DNA gyrase, HDAC7, rHA, RNR, TrxR, TS and Top II) are investigated by docking calculations. For examination of the docking results, the in vitro activities of eight compounds against the human leukemia cell line K562 was investigated by evaluation of $\mathrm{IC}_{50}$ values and mode of cell death (apoptosis).
\end{abstract}

Received 6th September 2018
Accepted 8th October 2018

DOI: 10.1039/c8ra07463a

rsc.li/rsc-advances
Compartmental Schiff bases, obtained by the condensation of salicylaldehyde or salicylaldehyde derivatives with diamines, have two cavities of different dimensions. ${ }^{18-22}$ Thus, these types of ligands can bind with one or two metal centers, enabling the successful synthesis of homo- and/or heteronuclear metal complexes with interesting stereochemistry. ${ }^{2023-25}$ Complexes derived from compartmental ligands have been widely studied over the last decades especially due to their applications as models of different metalloproteins. ${ }^{26-29}$

In order to extend the chemistry of the compartmental Schiff base compounds, in this work, the synthesis of a new ligand, 2,2'-((((((2-hydroxypropane-1,3-diyl)bis(oxy))bis(2,1-phenylene)) bis(methylene))bis(azanylylidene))bis(methanylylidene))bis(4bromophenol) $\left(\mathrm{H}_{3} \mathrm{~L}^{\mathrm{Br}}\right.$, Scheme 1) and its complexes with cobalt(II), copper(II) and zinc(II), $\left[\mathrm{Co}\left(\mathrm{HL}^{\mathrm{Br}}\right)\right](\mathbf{1}),\left[\mathrm{Cu}_{2}\left(\mathrm{~L}^{\mathrm{Br}}\right)(\mu-1,3-\right.$ $\mathrm{OAc})] \cdot \mathrm{MeOH}(2),\left[\mathrm{Zn}\left(\mathrm{HL}^{\mathrm{Br}}\right)\right]$ (3) are described, along with the characterization and theoretical studies.

In addition to the expected biological properties of the Schiff base compounds, ${ }^{30-35}$ binding the cobalt, copper and zinc atoms to this unit make these complexes a good prospect for biologically active compound $\mathrm{s}^{36-50}$ (31-35 for zinc, 36-40 for cobalt, 4145 for copper). For the study of the biological activities of new ligand $\left(\mathrm{H}_{3} \mathrm{~L}^{\mathrm{Br}}\right)$ and its complexes 1-3, docking calculations were run to investigate the possibility of interaction between these compounds with nine protein targets, including: BRAF kinase, cathepsin B (CatB), DNA gyrase, histone deacetylase (HDAC7), 


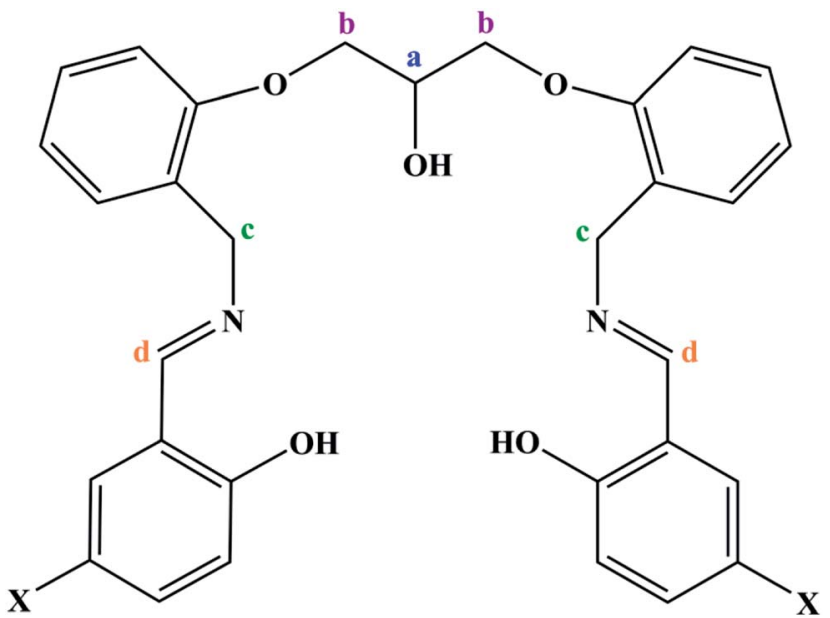

$\mathrm{X}: \mathrm{Br}\left(\mathrm{H}_{3} \mathrm{LBr}\right), \mathrm{NO}_{2}\left(\mathrm{H}_{3} \mathrm{~L}^{\mathrm{NO}_{2}}\right)$

Scheme 1 Structure of the two synthesized ligands $\left(\mathrm{H}_{3} \mathrm{~L}^{\mathrm{NO} 2}, \mathrm{H}_{3} \mathrm{~L}^{\mathrm{Br}}\right)$.

recombinant human albumin ( $\mathrm{rHA}$ ), ribonucleotide reductases (RNR), thioredoxin reductase (TrxR), thymidylate synthase (TS), topoisomerase II (Top II). ${ }^{51,52}$ These proteins were used in this project either due to their reported roles in the cancer growth or as transport agents that affect drug pharmacokinetic properties (e.g., rHA). Also, DNA gyrase was included to study the possibility of anticancer properties of the compounds also acting as antimalarial agents. ${ }^{53}$ Experimental investigations on the anticancer potential of all titled compounds, mode of cell death and apoptosis on the K562 cell lines were performed. The K562 cell line is a pluripotent precursor cell that is positive for the Philadelphia $(\mathrm{Ph})$ chromosome and was originally derived from a patient with human chronic myelogenous leukemia (CML) at the terminal stage of last crisis; this cell line is non-adherent and rounded, highly undifferentiated with an active proliferative capacity and the inhibition of apoptosis..$^{54}$

\section{Experimental}

\subsection{Materials and instrumentation}

All starting chemicals and solvents were reagent or analytical grade and used as received. The infrared spectra of $\mathrm{KBr}$ pellets in the range $4000-400 \mathrm{~cm}^{-1}$ were recorded with a FT-IR Shimadzu-IRprestige-21 spectrometer. The ${ }^{1} \mathrm{H}$ NMR spectra were recorded on Bruker Avance 400 instrument; chemical shifts $\delta$ are given in parts per million, relative to TMS as an internal standard. The carbon, hydrogen and nitrogen contents were determined in a Perkin-Elmer 2400 elemental analyzer. The melting points were determined with an Electrothermal 9100 electrically heated apparatus.

2.1.1 Synthesis of $2,2^{\prime}-(((()(2-h y d r o x y p r o p a n e-1,3-d i y l)$ bis(oxy))bis(2,1-phenylene))bis(methylene))bis(azanylylidene)) bis(methanylylidene))bis(4-bromophenol) $\left(\mathbf{H}_{3} \mathbf{L}^{\mathrm{Br}}\right)$. A solution of $0.402 \mathrm{~g}$ ( $2 \mathrm{mmol}$ ) of 5-bromo-2-hydroxybenzaldehyde, dissolved in methanol $(20 \mathrm{~mL})$, was added to a stirring solution of $0.302 \mathrm{~g}$ (1 mmol) of ((propane-1,3-diylbis(oxy))bis(2,1-phenylene)) dimethanamine (prepared according to the literature) ${ }^{55}$ in the

Table 1 Crystal data and structure refinement for complexes 1-3

\begin{tabular}{|c|c|c|c|}
\hline & Complex 1 & Complex 2 & Complex 3 \\
\hline Empirical formula & $\mathrm{C}_{31} \mathrm{H}_{26} \mathrm{Br}_{2} \mathrm{CoN}_{2} \mathrm{O}_{5}$ & $\mathrm{C}_{31} \mathrm{H}_{25} \mathrm{Br}_{2} \mathrm{Cu}_{2} \mathrm{~N}_{2} \mathrm{O}_{5}$ & $\mathrm{C}_{31} \mathrm{H}_{26} \mathrm{Br}_{2} \mathrm{~N}_{2} \mathrm{O}_{5} \mathrm{Zn}$ \\
\hline Formula weight, $\mathrm{g} \mathrm{mol}^{-1}$ & 725.29 & 792.43 & 731.73 \\
\hline Crystal size, $\mathrm{mm}^{3}$ & $0.27 \times 0.10 \times 0.06$ & $0.69 \times 0.37 \times 0.08$ & $0.22 \times 0.10 \times 0.07$ \\
\hline Temperature, $\mathrm{K}$ & 173 & 436 & 163 \\
\hline Crystal system & Triclinic & Monoclinic & Triclinic \\
\hline Space group & $P \overline{1}$ & $P 2_{1} / n$ & $P \overline{1}$ \\
\hline \multicolumn{4}{|l|}{ Unit cell dimensions $\left(\AA{ }^{\circ}{ }^{\circ}\right)$} \\
\hline$A$ & $7.1465(5)$ & $14.8266(10)$ & $7.1537(6)$ \\
\hline$B$ & $8.5993(6)$ & $12.0316(9)$ & $8.5883(6)$ \\
\hline$C$ & $24.5966(17)$ & $18.820(3)$ & $24.6179(17)$ \\
\hline$A$ & $93.136(7)$ & 90.000 & $92.958(7)$ \\
\hline$B$ & $96.008(7)$ & $96.213(7)$ & $96.172(7)$ \\
\hline$\Gamma$ & $106.846(7)$ & 90.000 & $106.824(7)$ \\
\hline Volume, $\AA^{3}$ & $1433.01(18)$ & $3337.6(6)$ & $1433.90(19)$ \\
\hline$Z$ & 2 & 4 & 2 \\
\hline Calculated density, $\mathrm{g} \mathrm{cm}^{-3}$ & 1.681 & 1.577 & 1.695 \\
\hline Absorption coefficient, $\mathrm{mm}^{-1}$ & 8.33 & 4.70 & 4.82 \\
\hline$F(000), \mathrm{e}$ & 726 & 1572 & 732 \\
\hline$\theta$ range for data collection $\left(^{\circ}\right)$ & $6.5-72.1$ & $6.9-72.0$ & $6.5-72.0$ \\
\hline$h, k, l$ ranges & $\begin{array}{l}-8 \leq h \leq 8,-10 \leq k \leq 9 \\
-29 \leq l \leq 30\end{array}$ & $\begin{array}{l}-18 \leq h \leq 14,-14 \leq k \leq 14 \\
-18 \leq l \leq 22\end{array}$ & $\begin{array}{l}-8 \leq h \leq 5,-10 \leq k \leq 10, \\
-30 \leq l \leq 30\end{array}$ \\
\hline Reflections collected/independent $/ R_{\text {int }}$ & $19872 / 5360 / 0.081$ & $27771 / 6330 / 0.081$ & $18870 / 5287 / 0.076$ \\
\hline Data/ref. parameters & $5360 / 371$ & $6330 / 436$ & $5287 / 371$ \\
\hline Goodness-of-fit on $F^{2}$ & 1.15 & 1.11 & 1.09 \\
\hline Final $R$ indexes $[I>=2 \sigma(I)]$ & $R_{1}=0.081, \mathrm{w} R_{2}=0.204$ & $R_{1}=0.075, \mathrm{w} R_{2}=0.197$ & $R_{1}=0.085, \mathrm{w} R_{2}=0.213$ \\
\hline Final $R$ indexes [all data] & $R_{1}=0.104, \mathrm{w} R_{2}=0.241$ & $R_{1}=0.093, \mathrm{w} R_{2}=0.231$ & $R_{1}=0.125, \mathrm{w} R_{2}=0.265$ \\
\hline Largest diff. peak/hole, e $\AA^{-3}$ & $0.63 /-1.09$ & $1.33 /-1.70$ & $0.73 /-1.00$ \\
\hline
\end{tabular}


Table 2 Selected bond length $(\AA)$ and angles $\left({ }^{\circ}\right)$ for complexes 1-3 with estimated standard deviations in parentheses

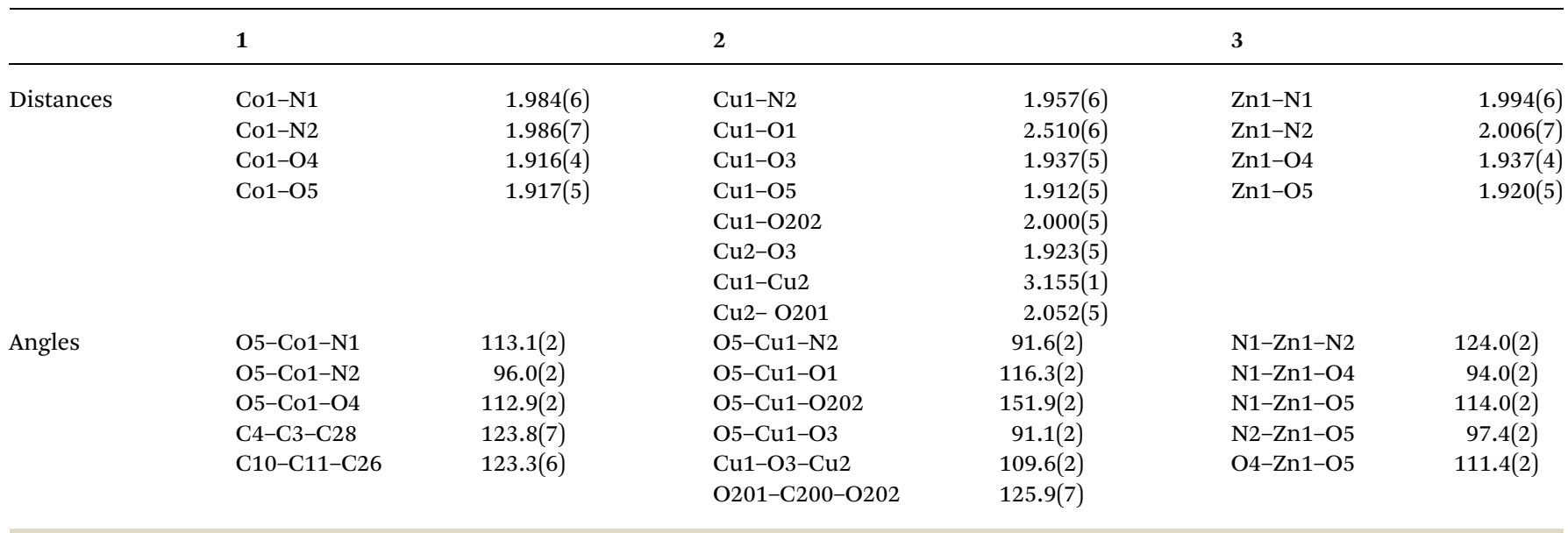

Table 3 Hydrogen bonds dimensions $\left(\AA ̊\right.$ and $\left.{ }^{\circ}\right)$ in complexes $1-3$

\begin{tabular}{lllllll}
\hline & $\mathrm{D}-\mathrm{H} \cdots \mathrm{A}$ & $d(\mathrm{D}-\mathrm{H})$ & $d(\mathrm{H} \cdots \mathrm{A})$ & $<(\mathrm{DHA})$ & $d(\mathrm{D} \cdots \mathrm{A})$ & Symmetry code on A atom \\
\hline $\mathbf{1}$ & $\mathrm{C}(26)-\mathrm{H}(26) \cdots \mathrm{O}(3)$ & 0.950 & 2.493 & 147.4 & $3.332(9)$ & $-1+x, y, z$ \\
& $\mathrm{O}(3)-\mathrm{H}(3) \cdots \mathrm{O}(4)$ & 0.840 & 1.914 & 150.9 & $2.679(7)$ & $1+x, 1+y, z$ \\
2 & $\mathrm{C}(17)-\mathrm{H}(17) \cdots \mathrm{O}(4)$ & 0.930 & 2.417 & 138.4 & $3.17(1)$ & $2-x, 1-y,-z$ \\
& $\mathrm{O}(300)-\mathrm{H}(300) \cdots \mathrm{O}(202)$ & 0.820 & 2.168 & 167.7 & $2.97(1)$ & $-1+x, y, z$ \\
\end{tabular}

same solvent $(20 \mathrm{~mL})$. The reaction mixture was heated under reflux for 4 hours to produce an oily compound which was died by rotary evaporation and then in air. Yield: $0.395 \mathrm{~g}, 59 \%$. Anal. calcd for $\mathrm{C}_{31} \mathrm{H}_{28} \mathrm{Br}_{2} \mathrm{~N}_{2} \mathrm{O}_{5}$ (668.38): C, 55.71; H, 4.22; N, 4.19. Found: C, 55.92; H, 4.25; N, 4.25\%. IR $\left(\mathrm{KBr}, \mathrm{cm}^{-1}\right): 3406 \mathrm{~s}(\nu \mathrm{O}-$ $\mathrm{H}), 3066 \mathrm{~m}(\nu \mathrm{C}-\mathrm{H})^{\mathrm{ar}}, 2931 \mathrm{~m}\left(\nu_{\mathrm{as}} \mathrm{CH}_{2}\right.$ and $/$ or $\left.\nu \mathrm{C}-\mathrm{H}\right), 2878 \mathrm{~m}\left(\nu_{\mathrm{s}}\right.$ $\left.\mathrm{CH}_{2}\right), 1635 \mathrm{~s}(\nu \mathrm{C}=\mathrm{N}), 1478 \mathrm{~s}$ and $1601 \mathrm{~m}\left(\nu \mathrm{C}=\mathrm{C}^{\mathrm{ar}}\right), 1451 \mathrm{~m}\left(\delta_{\mathrm{as}}\right.$ $\left.\mathrm{CH}_{2}\right), 1370 \mathrm{~m}\left(\delta_{\mathrm{s}} \mathrm{CH}_{2}\right), 1250 \mathrm{~s}\left(\nu_{\text {as }} \mathrm{C}-\mathrm{O}-\mathrm{C}\right)^{\mathrm{Ether}}, 1119 \mathrm{~m}\left(\nu_{\mathrm{s}} \mathrm{C}-\mathrm{O}-\right.$ $\mathrm{C})^{\text {Ether }}, 1038 \mathrm{~s}(\nu \mathrm{C}-\mathrm{N}) .{ }^{1} \mathrm{H}$ NMR $\left(400 \mathrm{MHz}, \mathrm{CDCl}_{3}, \mathrm{ppm}, \mathrm{Hz}\right): \delta=$ $9.8\left(\mathrm{~s}, 2 \mathrm{H}, \mathrm{OH}^{\text {Phenol }}\right), 8.3 \mathrm{~s}, 2 \mathrm{H}, \mathrm{C}^{\mathrm{d}} \mathrm{H}, 6.6-7.6 \mathrm{~m}, 14 \mathrm{H}, \mathrm{CH}^{\mathrm{ar}}, 4.9 \mathrm{~s}$, $1 \mathrm{H}, \mathrm{OH}^{\text {Alcohol }}, 4.8 \mathrm{~s}, 4 \mathrm{H}, \mathrm{C}^{\mathrm{c}} \mathrm{H}, 4.5 \mathrm{~m}, 1 \mathrm{H}, \mathrm{C}^{\mathrm{a}} \mathrm{H}, 4.2 \mathrm{~d}, 4 \mathrm{H}, \mathrm{C}^{\mathrm{b}} \mathrm{H}$.

2.1.2 Synthesis of $\left[\mathbf{C o}\left(\mathbf{H L}^{\mathrm{Br}}\right)\right]$ (1). ((Propane-1,3-diylbis(oxy)) bis(2,1-phenylene) )dimethanamine $(0.302 \mathrm{~g}, 1 \mathrm{mmol})$ was dissolved in methanol $(10 \mathrm{~mL})$ on heating with successive addition of a methanolic solution $(10 \mathrm{~mL})$ of 5-bromo-2hydroxybenzaldehyde $(0.33 \mathrm{~g}, 2 \mathrm{mmol})$ and $\mathrm{Co}(\mathrm{OAc})_{2} \cdot 4 \mathrm{H}_{2} \mathrm{O}$ $(0.25 \mathrm{~g}, 1 \mathrm{mmol})$. The reaction mixtures were stirred for $4 \mathrm{~h}$ under reflux and allowed to stand at room temperature.

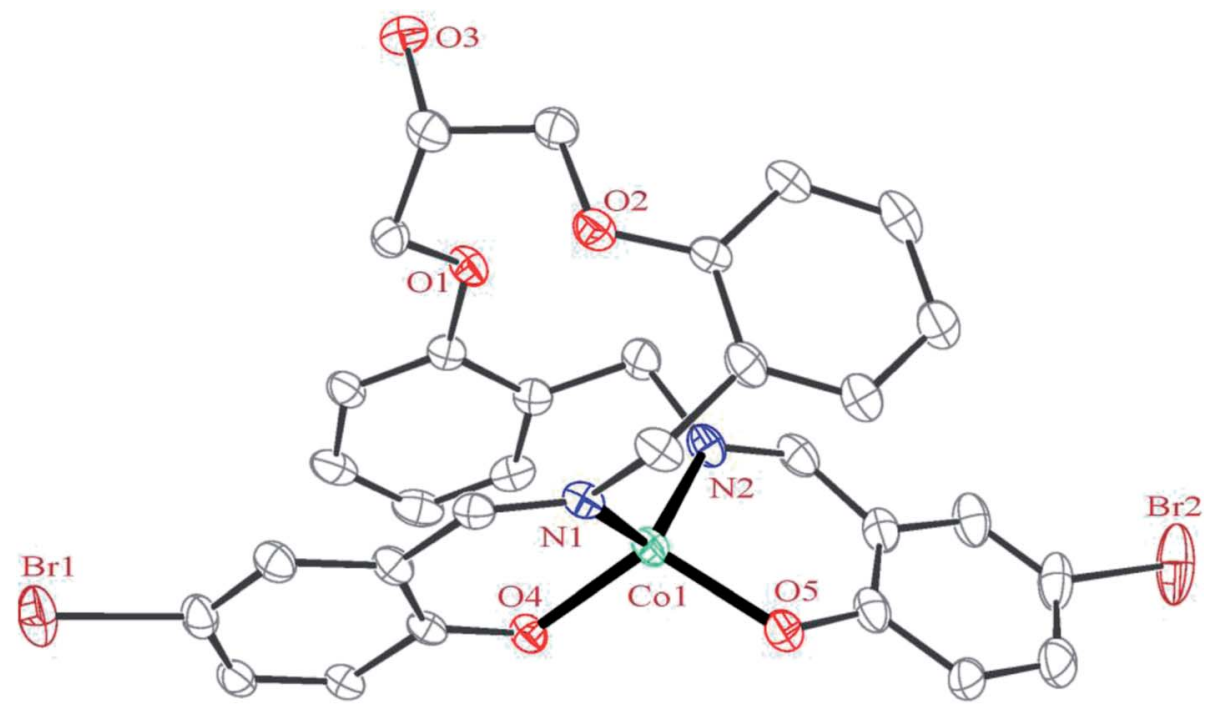

Fig. 1 ORTEP diagram of the molecular structure of 1 . The ellipsoids are drawn at the $20 \%$ probability level. The hydrogen atoms were deleted for clarity. 


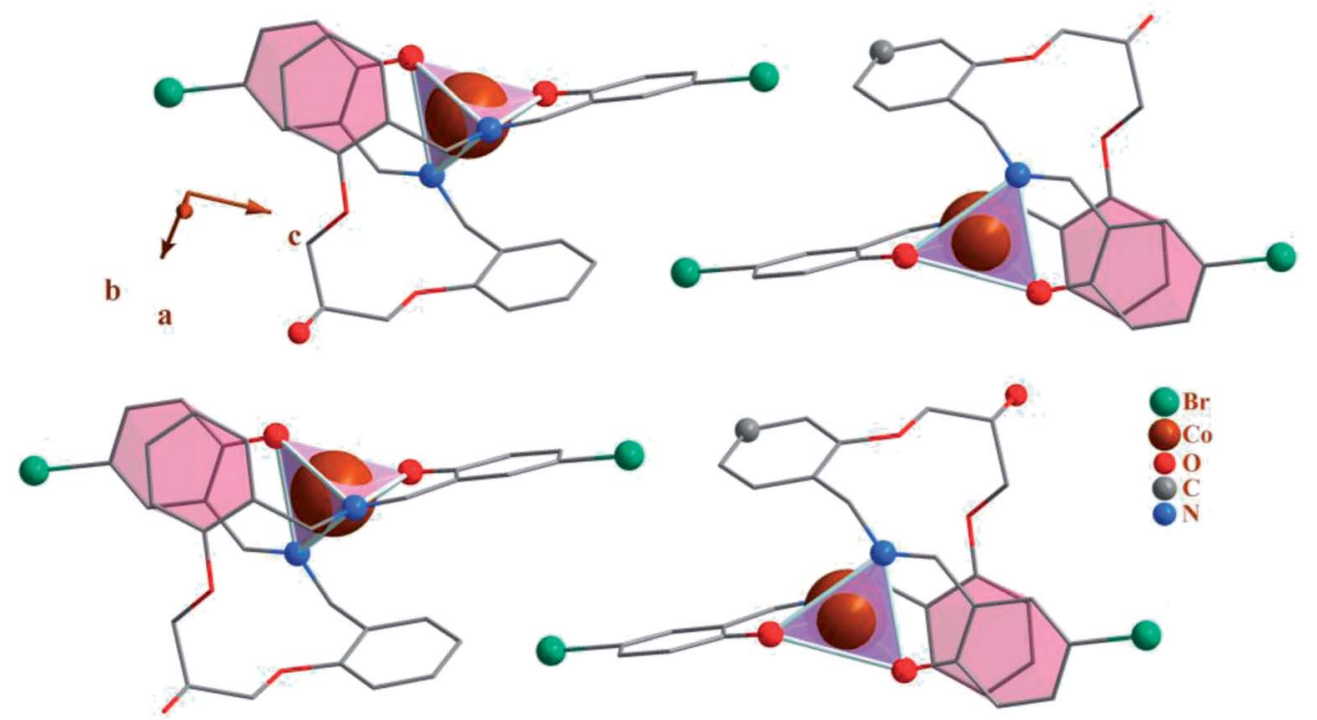

Fig. 2 Packing of 1 , showing the $\pi-\pi$ stacking interactions. Each $\mathrm{CoN}_{2} \mathrm{O}_{2}$ unit is shown as tetrahedron.

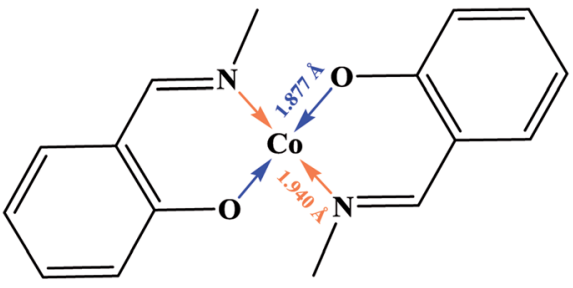

(a)

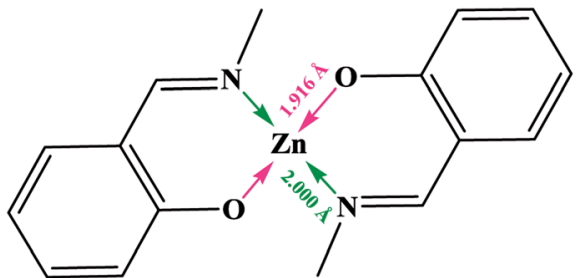

(b)

Scheme 2 Coordinated bond lengths average for all cobalt (a) and zinc (b) complexes containing the presented moiety.

Obtained solids were collected by filtration, washed with methanol, and dried in air. The precipitates were recrystallized in mixture of chloroform and methanol and after a few days crystals suitable for X-ray data analysis were obtained from this solution. Yield: $0.35 \mathrm{~g}, 49 \%$; $\mathrm{mp} 265^{\circ} \mathrm{C}$ decomposed. Anal. calcd for $\mathrm{C}_{31} \mathrm{H}_{26} \mathrm{Br}_{2} \mathrm{CoN}_{2} \mathrm{O}_{5}$ (725.29): C, 51.34; $\mathrm{H}, 3.61 ; \mathrm{N}, 3.86$. Found: C, $51.47 ; \mathrm{H}, 3.69 ; \mathrm{N}, 3.82 \%$. IR $\left(\mathrm{KBr}, \mathrm{cm}^{-1}\right): 3415 \mathrm{~m}(\nu \mathrm{O}-\mathrm{H}), 3070$ $\mathrm{m}(\nu \mathrm{C}-\mathrm{H})^{\text {ar }}, 2920 \mathrm{~m}\left(\nu_{\text {as }} \mathrm{CH}_{2}\right.$ and/or $\left.\nu \mathrm{C}-\mathrm{H}\right), 2875 \mathrm{~m}\left(\nu_{\mathrm{s}} \mathrm{CH}_{2}\right)$, $1608 \mathrm{~s}(\nu \mathrm{C}=\mathrm{N}), 1478 \mathrm{~s}$ and $1520 \mathrm{~m}\left(\nu \mathrm{C}=\mathrm{C}^{\mathrm{a}}\right), 1419 \mathrm{~m}\left(\delta_{\mathrm{as}} \mathrm{CH}_{2}\right)$,

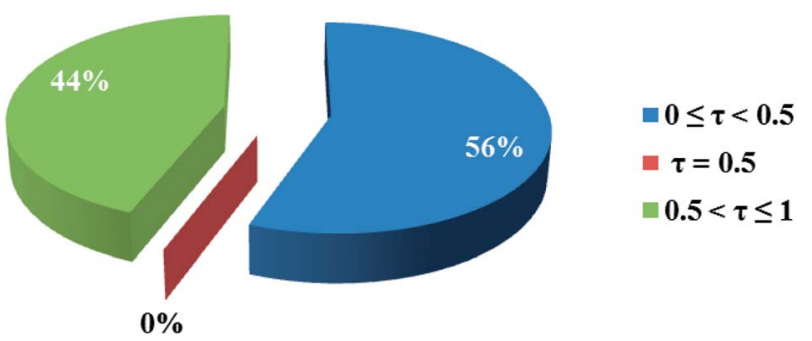

Fig. 3 Pie chart, the percentage of different geometries around the cobalt atom among the analogues of the complex 1 . Geometry for $\tau_{\text {sq }}$ values lower than the 0.5 is tetrahedron and higher than the 0.5 is square plane.
$1370 \mathrm{~m}\left(\delta_{\mathrm{s}} \mathrm{CH}_{2}\right), 1249 \mathrm{~m}\left(\nu_{\mathrm{as}} \mathrm{C}-\mathrm{O}-\mathrm{C}\right)^{\mathrm{Ether}}, 1120 \mathrm{~m}\left(\nu_{\mathrm{s}} \mathrm{C}-\mathrm{O}-\right.$ C) ${ }^{\text {Ether }}, 1037 \mathrm{~m}(\nu \mathrm{C}-\mathrm{N})$.

2.1.3 Synthesis of $\left[\mathrm{Cu}_{2}\left(\mathrm{~L}^{\mathrm{Br}}\right)(\mu-1,3-\mathrm{OAc})\right] \cdot \mathrm{MeOH}$ (2). The procedure for synthesis of 2 was similar to 1 except that the $\mathrm{Co}(\mathrm{OAc})_{2} \cdot 4 \mathrm{H}_{2} \mathrm{O}$ was replaced by $\mathrm{Cu}(\mathrm{OAc})_{2} \cdot 4 \mathrm{H}_{2} \mathrm{O}(0.25 \mathrm{~g}, 1$ mmol). Yield: $0.44 \mathrm{~g}, 56 \% ; \mathrm{mp} 233{ }^{\circ} \mathrm{C}$ decomposed. Anal. calcd for $\mathrm{C}_{31} \mathrm{H}_{25} \mathrm{Br}_{2} \mathrm{Cu}_{2} \mathrm{~N}_{2} \mathrm{O}_{5}$ (792.43): C, 46.99; $\mathrm{H}, 3.18 ; \mathrm{N}, 3.54$. Found: C, $46.82 ; \mathrm{H}, 3.17 ; \mathrm{N}, 3.55 \%$. IR $\left(\mathrm{KBr}, \mathrm{cm}^{-1}\right): 3426 \mathrm{~m}(\nu \mathrm{O}-$ $\mathrm{H}), 3120 \mathrm{w}(\nu \mathrm{C}-\mathrm{H})^{\mathrm{ar}}, 2930 \mathrm{w}\left(\nu_{\mathrm{as}} \mathrm{CH}_{2}\right.$ and $/$ or $\left.\nu \mathrm{C}-\mathrm{H}\right), 2875 \mathrm{w}\left(\nu_{\mathrm{s}}\right.$ $\left.\mathrm{CH}_{2}\right), 1631 \mathrm{~s}\left(\nu_{\text {as }} \mathrm{COO}\right), 1605 \mathrm{~m}(\nu \mathrm{C}=\mathrm{N}), 1493 \mathrm{~m}$ and $1562 \mathrm{~m}(\nu$ $\left.\mathrm{C}=\mathrm{C}^{\mathrm{ar}}\right), 1454 \mathrm{~s}\left(\delta_{\mathrm{as}} \mathrm{CH}_{2}\right), 1389 \mathrm{~m}\left(\delta_{\mathrm{s}} \mathrm{CH}_{2}\right), 1319 \mathrm{~m}\left(\nu_{\mathrm{s}} \mathrm{COO}\right)$, $1242 \mathrm{~m}\left(\nu_{\text {as }} \mathrm{C}-\mathrm{O}-\mathrm{C}\right)^{\text {Ether }}, 1119 \mathrm{~m}\left(\nu_{\mathrm{s}} \mathrm{C}-\mathrm{O}-\mathrm{C}\right)^{\mathrm{Ether}}, 1026 \mathrm{~m}(\nu \mathrm{C}-\mathrm{N})$, $646 \mathrm{~m}(\delta$ OCO).

2.1.4 Synthesis of $\left[\mathrm{Zn}\left(\mathrm{HL}^{\mathrm{Br}}\right)\right]$ (3). The procedure for synthesis of 3 was similar to 1 except that the $\mathrm{Co}(\mathrm{OAc})_{2} \cdot 4 \mathrm{H}_{2} \mathrm{O}$ was replaced by $\mathrm{Zn}(\mathrm{OAc})_{2} \cdot 2 \mathrm{H}_{2} \mathrm{O}(0.22 \mathrm{~g}, 1 \mathrm{mmol})$. Yield: $0.37 \mathrm{~g}, 51 \% ; \mathrm{mp} 290^{\circ} \mathrm{C}$ decomposed. Anal. calcd for $\mathrm{C}_{31} \mathrm{H}_{26} \mathrm{Br}_{2} \mathrm{~N}_{2} \mathrm{O}_{5} \mathrm{Zn}$ (731.73): C, 50.88; $\mathrm{H}, 3.58 ; \mathrm{N}, 3.83$. Found: $\mathrm{C}, 50.96 ; \mathrm{H}, 3.60 ; \mathrm{N}, 3.90 \%$. IR $\left(\mathrm{KBr}, \mathrm{cm}^{-1}\right)$ : $3426 \mathrm{~m}(\nu \mathrm{O}-\mathrm{H}), 3071 \mathrm{w}(\nu \mathrm{C}-\mathrm{H})^{\mathrm{ar}}, 2916 \mathrm{w}\left(\nu_{\text {as }} \mathrm{CH}_{2}\right.$ and/or $\left.\nu \mathrm{C}-\mathrm{H}\right)$, $2850 \mathrm{w}\left(\nu_{\mathrm{s}} \mathrm{CH}_{2}\right), 1620 \mathrm{~s}(\nu \mathrm{C}=\mathrm{N}), 1496 \mathrm{~m}$ and $1520 \mathrm{~m}\left(\nu \mathrm{C}=\mathrm{C}^{\mathrm{ar}}\right)$, $1458 \mathrm{~s}\left(\delta_{\text {as }} \mathrm{CH}_{2}\right), 1389 \mathrm{~m}\left(\delta_{\mathrm{s}} \mathrm{CH}_{2}\right), 1250 \mathrm{~m}\left(\nu_{\text {as }} \mathrm{C}-\mathrm{O}-\mathrm{C}\right)^{\mathrm{Ether}}, 1119 \mathrm{w}$ $\left(\nu_{\mathrm{s}} \mathrm{C}-\mathrm{O}-\mathrm{C}\right)^{\mathrm{Ether}}, 1034 \mathrm{~m}(\nu \mathrm{C}-\mathrm{N}) \cdot{ }^{1} \mathrm{H}$ NMR $(400 \mathrm{MHz}$, DMSO$\left.d_{6}, \mathrm{ppm}, \mathrm{Hz}\right): \delta=8.3 \mathrm{~s}, 2 \mathrm{H}, \mathrm{C}^{\mathrm{d}} \mathrm{H}, 6.3-7.4 \mathrm{~m}, 14 \mathrm{H}, \mathrm{CH}^{\mathrm{ar}}, 4.8 \mathrm{~s}, 1 \mathrm{H}$, $\mathrm{OH}^{\text {Alcohol }}, 4.5 \mathrm{~m}, 1 \mathrm{H}, \mathrm{C}^{\mathrm{a}} \mathrm{H}, 4.2 \mathrm{~d}, 4 \mathrm{H}, \mathrm{C}^{\mathrm{b}} \mathrm{H}, 4.1 \mathrm{~s}, 4 \mathrm{H}, \mathrm{C}^{\mathrm{c}} \mathrm{H}$. 

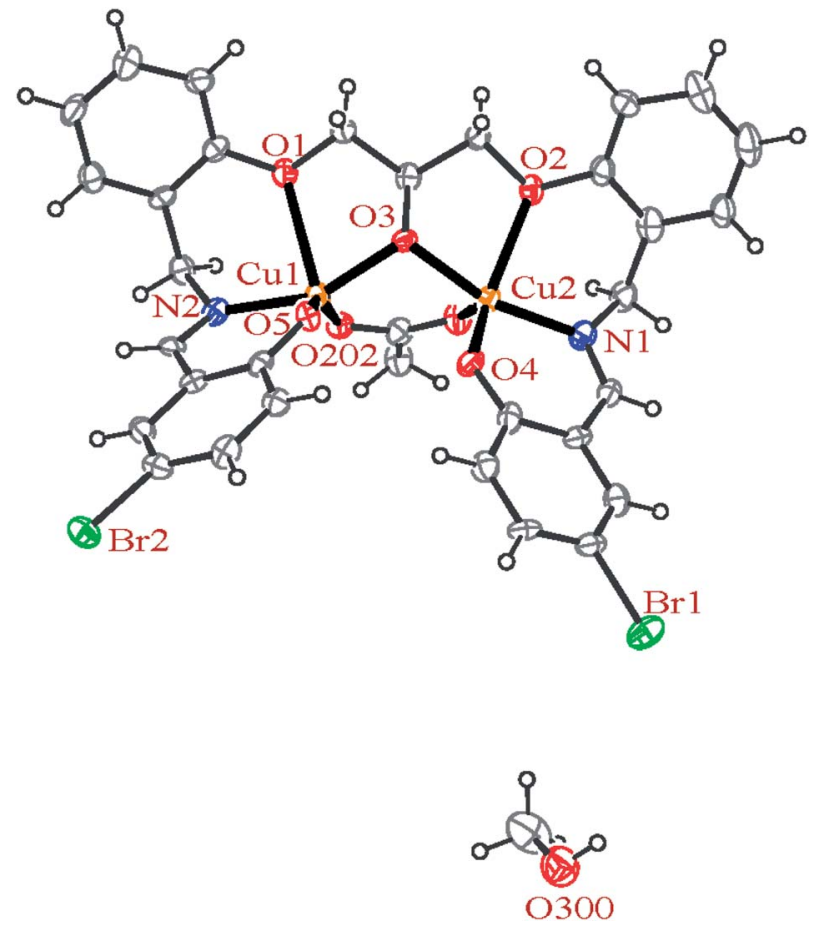

Fig. 4 ORTEP diagram of the molecular structure of 2 . The ellipsoids are drawn at the $20 \%$ probability level.

\subsection{Crystal structure determination}

Crystals were mounted on a glass fibre using perfluoropolyether oil and the sample cooled to the required temperature in a stream of cold nitrogen. The diffraction data of complexes 1-3 were collected on a Rigaku Spider diffractometer equipped with a MicroMax MM007 rotating anode generator, $\mathrm{Cu}_{\alpha}$ radiation $(\lambda$ $=1.54178 \AA$ A), high-flux Osmic multilayer mirror optics, and a curved image-plate detector. The data were integrated, scaled and averaged with FS Process. In the case of complexes 4-6, data were collected on a Bruker Kappa diffractometer with graphite monochromated Mo-K $\mathrm{K}_{\alpha}(\lambda=0.71073 \AA)$. After data collection, in each case an empirical absorption correction was applied. The structures were then solved by direct methods and refined on all $F^{2}$. In all cases non-hydrogen atoms were refined with anisotropic thermal parameters; hydrogen atoms were included in calculated positions and refined with isotropic thermal parameters which were ca. $1.2 \times$ (aromatic $\mathrm{CH}$ ) or $1.5 \times(\mathrm{Me}$, $\left.\mathrm{CH}_{2}, \mathrm{OH}\right)$ the equivalent isotropic thermal parameters of their parent carbon atoms. The data were corrected for Lorentz and polarization effects. The programs used in this work are Bruker Saint Plus, including X-RED and X-Shape for data reduction and absorption correction, and the SHELX and OLEX program suites. ${ }^{56}$ Diagrams of the molecular structure and unit cell were created using Ortep-III ${ }^{57,58}$ and Diamond ${ }^{59}$ software. Details of crystal data, data collection, structure solutions and refinements are given in Table 1. Selected bond lengths and angles of complexes are listed in Table 2 and hydrogen bond geometries in Table 3.

\subsection{Computational details}

All structures were optimized with the Gaussian 09 software $^{60}$ and calculated for an isolated molecule using Density Functional Theory $(\mathrm{DFT})^{\mathbf{6 1}}$ at the B3LYP/LanL2DZ level of theory as well as for NBO analysis. Cif files of the complexes were used as input file for theoretical calculations.

\subsection{Docking details}

The pdb files 4r5y, 3ai8, 5cdn, 3c0z, 2bx8, 1peo, 3qfa, 1njb, 4gfh for the nine receptors, BRAF kinase, cathepsin B (CatB), DNA gyrase, histone deacetylase (HDAC7), recombinant human

Table 4 All coordination modes of the acetato ligand with copper atom

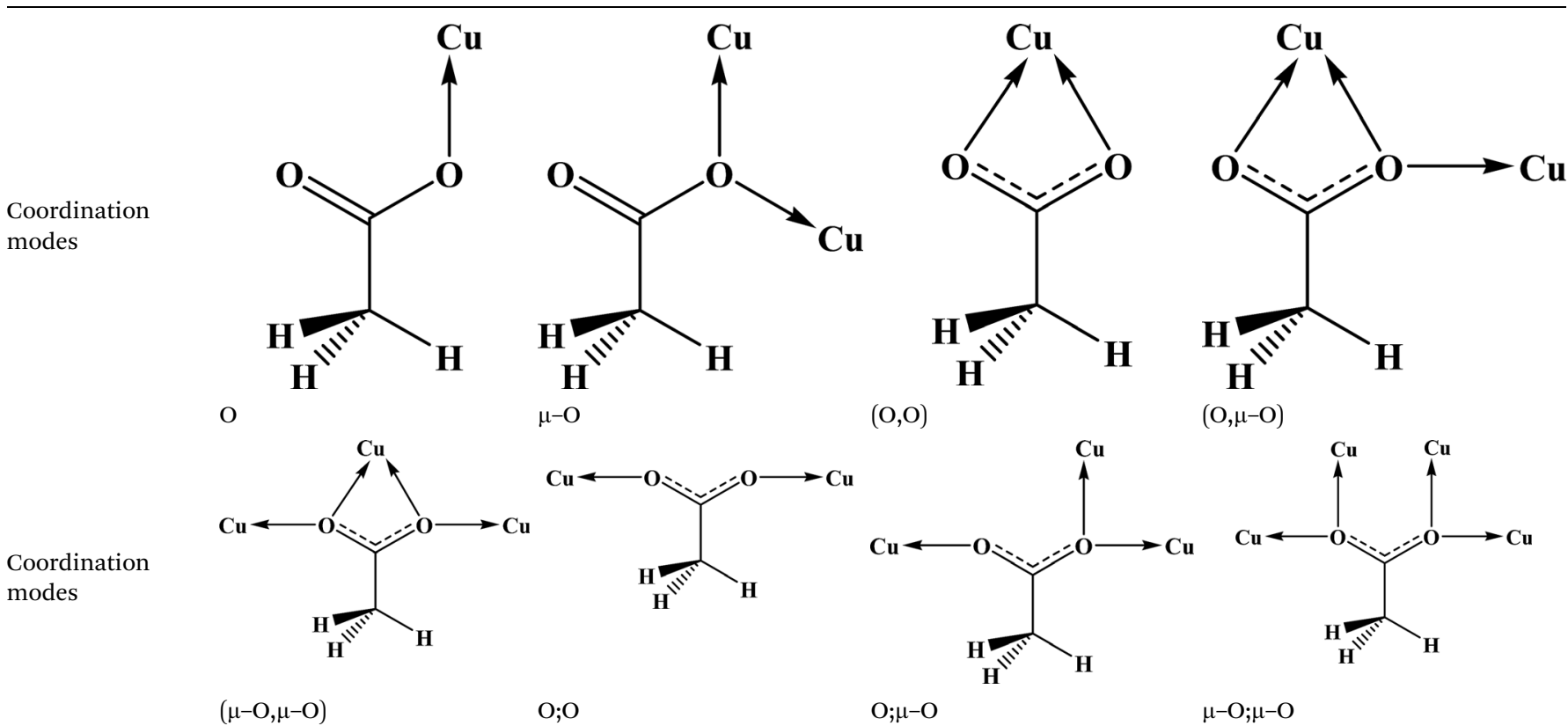



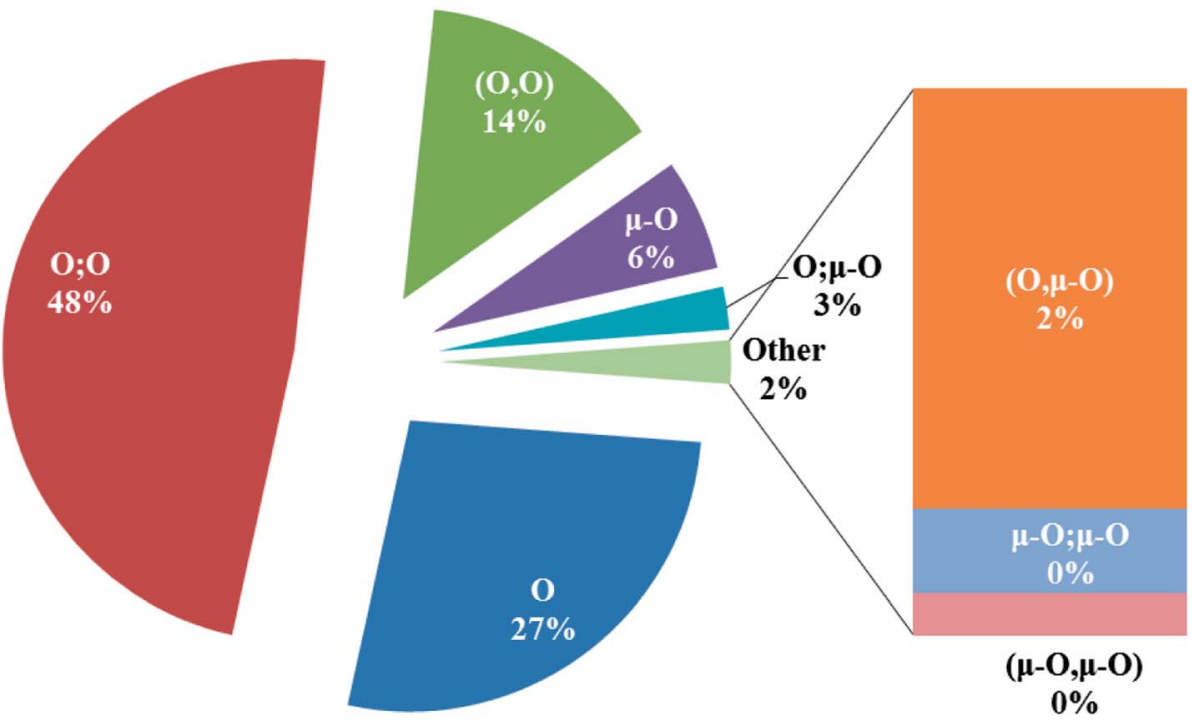

Fig. 5 Pie chart, the percentage of different coordination modes of the acetato ligand among the complexes of the copper.

albumin (rHA), ribonucleotide reductases (RNR), thioredoxin reductase (TrxR), thymidylate synthase (TS), topoisomerase II (Top II), respectively, used in this research were obtained from the Protein Data Bank (pdb). ${ }^{62}$ The obtained full version of Genetic Optimisation for Ligand Docking (GOLD) 5.5 (ref. 63) was used for the docking. The Hermes visualizer in the GOLD Suite was used to further prepare the structures and the receptors for docking. The optimized $\mathrm{H}_{3} \mathrm{~L}^{\mathrm{Br}}$ ligand and also cif file of the complexes 1-3 were used for docking studies. The region of interest used for Gold docking was defined as all the protein residues within the $6 \AA$ of the reference ligand " $\mathrm{A}$ " that accompanied the downloaded protein. All free water molecules in the structure of the proteins were deleted before docking. Default values of all other parameters were used and the complexes were submitted to 10 genetic algorithm runs using the GOLDScore fitness function.

\subsection{Biological evaluation}

2.5.1 Materials. Fetal bovine serum (FBS), propidium iodide and (PI), acridine orange (AO) 3-(4, 5-dimethylthiazol-2yl)-2,5-diphenyl tetrazolium bromide (MTT) was obtained from Sigma Aldrich. RPMI-1640 medium was obtained from Gibco (UK). Dimethyl sulfoxide (DMSO) was obtained from Merck. Fluorescent studies were done by fluorescent microscope (OLYMPUS, USA).

2.5.2 Cell culture and treatments. Human leukemia cell line K562 and its adriamycin-selected multidrug resistant subline K562/ADM were obtained from the Pasteur Institute of

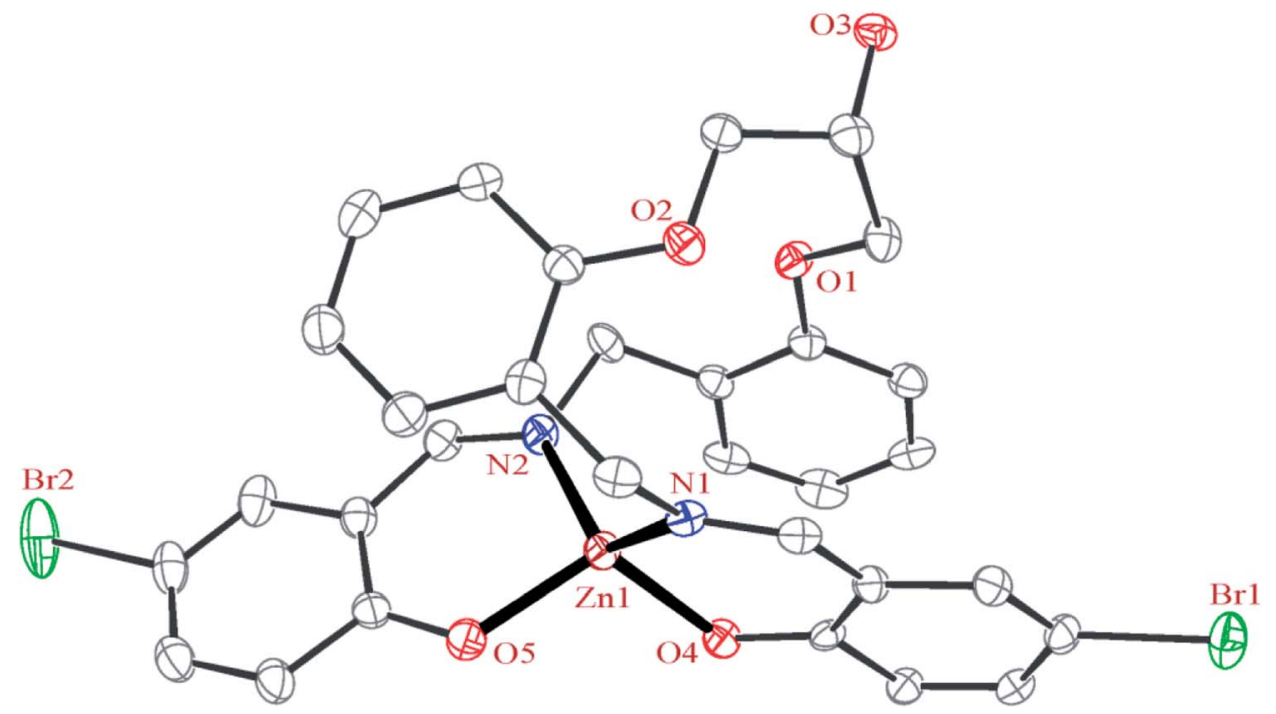

Fig. 6 ORTEP diagram of the molecular structure of 3. The ellipsoids are drawn at the $20 \%$ probability level. The hydrogen atoms were deleted for clarity. 


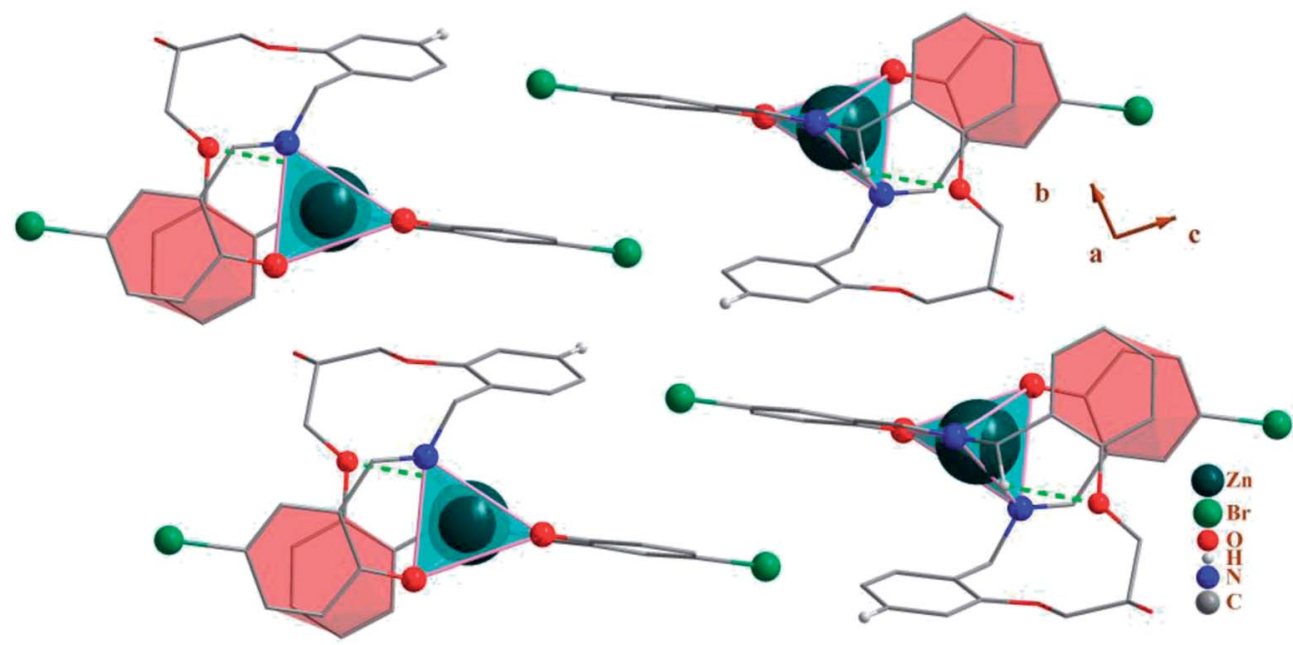

Fig. 7 Packing of 3 , showing the $\pi-\pi$ stacking and hydrogen bonds. Each $\mathrm{ZnN}_{2} \mathrm{O}_{2}$ unit is shown as tetrahedron.

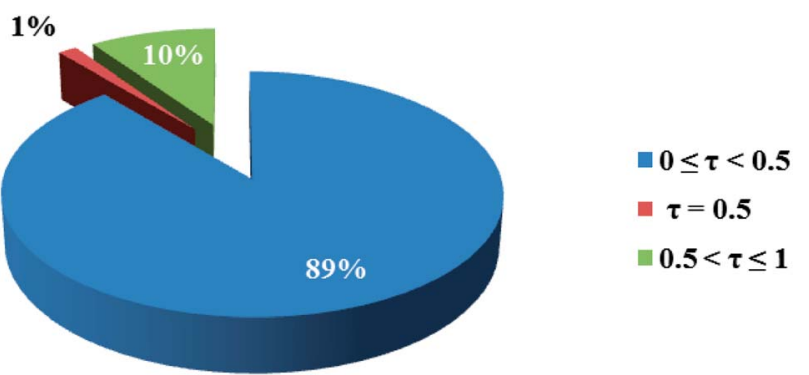

Fig. 8 Pie chart, the percentage of different geometries around the zinc atom among the analogues of the complex 3. Geometry for $\tau$ values lower than the 0.5 is square pyramid and higher than the 0.5 is trigonal bi pyramid.

Iran. All the cell lines were grown in RPMI 1640 medium containing $10 \%$ bovine serum (FBS) and $100 \mathrm{U} \mathrm{mL}^{-1}$ penicillin and $100 \mu \mathrm{g}$ streptomycin (BIOCERA) at $37{ }^{\circ} \mathrm{C}$ in a humidified $5 \%$ $\mathrm{CO}_{2}$ incubator. To maintain MDR phenotype, $1 \mathrm{mg} \mathrm{L}^{-1}$ adriamycin was added to K562/ADM cultures and maintained in the drug-free medium for at least two weeks before being used. Compounds were dissolved in $180 \mu \mathrm{L}$ of DMSO for in vitro assays.

2.5.3 The MTT assay. Cells were cultured at a density of $1 \times$ $10^{4} / 100 \mu \mathrm{L}$ in a 96-well plate and allowed to attach overnight. After the incubation with the testing chemicals for $48 \mathrm{~h}$ and
$72 \mathrm{~h}$, the cells were treated with the solution of MTT $(5 \mathrm{mg}$ $\mathrm{mL}^{-1}$ ) at $37^{\circ} \mathrm{C}$ for $4 \mathrm{~h}$. The absorbance was measured at $498 \mathrm{~nm}$ using a microplate reader (Multiskan Spectrum, Thermo Scientific). The inhibition rates were calculated on a plate-byplate basis for the test wells. The $\mathbf{I C}_{50}$ values were calculated based on the inhibitory rate curves using Bliss' method.

2.5.4 AO/PI staining assay. Briefly, after treatment for $24 \mathrm{~h}$ with compounds, K562 cells were harvested, centrifuged at $400 \mathrm{rpm}$ for $10 \mathrm{~min}$ and washed in PBS. Then $1 \mathrm{~mL}$ were incubated in the dark with $\mathrm{AO}(10 \mu \mathrm{L})$ and $\mathrm{PI}(10 \mu \mathrm{L})$ for $15 \mathrm{~min}$. After mixing the suspension with a solution of $\mathrm{AO} / \mathrm{PI}$, analysis was performed under a fluorescence microscope. While a green fluorescence showed apoptosis, a red colored nucleus indicated necrotic cells.

\section{Results and discussion}

Two Schiff base ligand were made in one-pot syntheses by condensation of 5-bromo-2-hydroxybenzaldehyde with diamine precursors in a $2: 1$ molar ratio. Three complexes 1-3 have been synthesized by template condensation of mentioned aldehyde and diamine at the presence of the $\mathrm{M}(\mathrm{OAc})_{2}$ ( $\mathrm{M}$ : $\mathrm{Co}(\mathbf{1}), \mathrm{Cu}(2)$, $\mathrm{Zn}(3))$. The complexes are air-stable and soluble in DMSO.

\subsection{Spectroscopic characterization}

In the IR spectrum of the $\mathrm{H}_{3} \mathrm{~L}^{\mathrm{Br}}$, a broad absorption band at above $3400 \mathrm{~cm}^{-1}$ due to the vibration of the alcoholic unit

Table $5 \pi-\pi$ stacking interactions dimensions $\left(\AA\right.$ and $\left.{ }^{\circ}\right)$ in complexes 1 and 3

\begin{tabular}{llllll}
\hline & $\begin{array}{l}\text { Centroid-centroid } \\
\text { distance }\end{array}$ & $\begin{array}{l}\text { Angle between } \\
\text { the planes }\end{array}$ & Perpendicular distance & Slippage & Type \\
\hline $\mathbf{1}$ & 3.883 & 8.65 & - & - & Intra \\
$\mathbf{3}$ & 3.697 & 8.65 & - & - & Inter \\
& 3.881 & 9.68 & - & - & Intra \\
& 3.700 & 9.68 & - & - & Inter \\
& 3.749 & 6.37 & - & - & Intra \\
& 3.673 & 6.37 & & & Inter
\end{tabular}




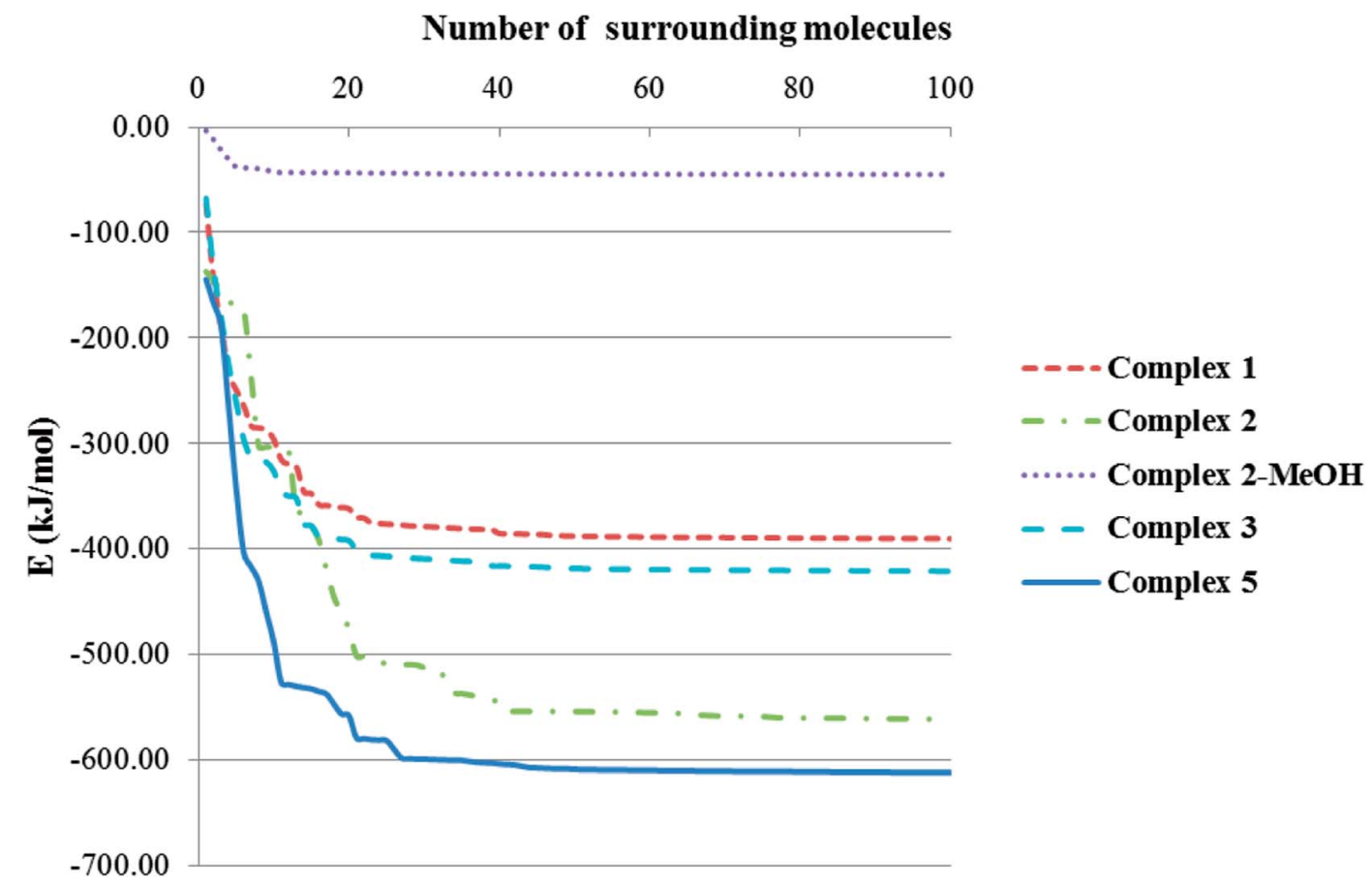

Fig. 9 Variation diagram of total intermolecular interactions energy $(E)$ for complexes $1-3$ with increasing the number of surrounding molecules.

Table 6 The NBO analysis results for the complexes 2 and 3 and $\mathrm{H}_{3} \mathrm{~L}^{\mathrm{Br}}$. The values are the total of charge on the similar atoms. The values of parentheses show the variation of charge on the atoms after coordination

\begin{tabular}{|c|c|c|c|c|c|c|c|c|c|c|c|}
\hline & $\mathrm{C}$ & $\mathrm{C}^{\mathrm{OAc}}$ & $\mathrm{H}$ & $\mathrm{H}^{\mathrm{OAc}}$ & $\mathrm{N}$ & $\mathrm{N}^{\mathrm{NO} 2}$ & $\mathrm{O}$ & $\mathrm{O}^{\mathrm{NO} 2}$ & $\mathrm{O}^{\mathrm{OAc}}$ & $\mathrm{Br}$ & Metal \\
\hline $\mathrm{H}_{3} \mathrm{~L}^{\mathrm{Br}}$ & -2.75 & - & 7.08 & - & -0.93 & - & -3.49 & - & - & 0.09 & - \\
\hline Complex 2 & $-2.44(+0.31)$ & 0.17 & $5.56(-1.52)$ & 0.71 & $-1.11(-0.18)$ & - & $-3.30(+0.19)$ & - & -1.46 & $0.06(-0.03)$ & 1.81 \\
\hline
\end{tabular}

which is shifted to the higher frequencies $\left(9-20 \mathrm{~cm}^{-1}\right)$ after complexation in 1-3. The weak peaks at above and below the $3000 \mathrm{~cm}^{-1}$ are compatible with the aromatic and aliphatic moieties in the structure of the all compounds, respectively. The $\nu(\mathrm{C}=\mathrm{N})$ peak in the complexes shifted to the lower frequencies (4-30 $\left.\mathrm{cm}^{-1}\right)$, confirming the coordination of this unit to the metal centers. In the spectra of the all structures, the frequencies near 1250 and $1100 \mathrm{~cm}^{-1}$ which can be assigned to the asymmetric and symmetric stretching vibrations of the ether group revealed that the etheric oxygen site in these structures.

In the FT-IR spectrum of 2, three bands near 1640, 1320 and $650 \mathrm{~cm}^{-1}$ were assigned to the $\nu_{\text {as }}(\mathrm{COO}), \nu_{\mathrm{s}}(\mathrm{COO})$ and $\delta(\mathrm{OCO})$ respectively, confirming the presence of the acetato ligand. The differences between asymmetric $\left(\nu_{\mathrm{as}}\right)$ and symmetric $\left(\nu_{\mathrm{s}}\right)$ stretching of the acetate group $(\Delta)$ can reveal its coordination type. In monodentate complexes, $\Delta$ values are much greater than the acetate salt $\left(164 \mathrm{~cm}^{-1}\right)$ while in bidentate complexes these values are significantly less than the acetate salt. ${ }^{64,65}$ The $\Delta$ value for 2 is $312 \mathrm{~cm}^{-1}$ suggests pseudo-monodentate coordination, which is consistent with the literature structure. ${ }^{66}$

To interpret the NMR spectra, some carbon atoms of the ligands are marked in Scheme 1. In the NMR spectrum of ligand, the signal of the phenolic hydrogen atoms is observed at the lowest magnetic field and was not observed in the spectra of the 3 , confirming the deprotonation of them during the complexation process. In the downfield region, there are other signals that can be assigned to the aromatic and imine protons. The aliphatic protons are observed at the range of 4-5 ppm.

\subsection{Description of the crystal structures}

3.2.1 Crystal structure of $\left[\mathrm{Co}\left(\mathrm{HL}^{\mathrm{Br}}\right)\right]$ (1). In this structure (Fig. 1), the cobalt atom is coordinated by two nitrogen and two oxygen atoms of the $\mathrm{HL}^{\mathrm{Br}}$ with coordination number of four. The tetracoordinate geometry of cobalt atom can adopt either a tetrahedral or a square planar configuration. To determine the geometry of such structures, the formula of Hakimi et al. ${ }^{67}$ was applied in which the angular structural parameter $\left(\tau_{\mathrm{sq}}\right)$ is represented as the index of tetragonality. The parameter $\tau_{\mathrm{sq}}=\left(\theta_{\max }\right.$ - $\left.\theta_{\min }\right) / 90$, where $\theta_{\max }$ and $\theta_{\min }$ are the maximum and minimum bond angles, respectively. An ideal square plane will have $\theta_{\max }=180^{\circ}$ and $\theta_{\min }=90^{\circ}$, and therefore $\tau_{\mathrm{sq}}=1$, but an ideal tetrahedron will have $\theta_{\max }=109.28^{\circ}, \theta_{\min }=109.28^{\circ}$ and therefore $\tau_{\mathrm{sq}}=0$. The $\tau_{\mathrm{sq}}$ value is calculated to be 0.33 in $\mathbf{1}$, indicating a propensity to a tetrahedral geometry (Fig. 1 and 2). Analysis of the CSD database revealed that the common geometry for analogues of $\mathbf{1}$ (structures containing the base 


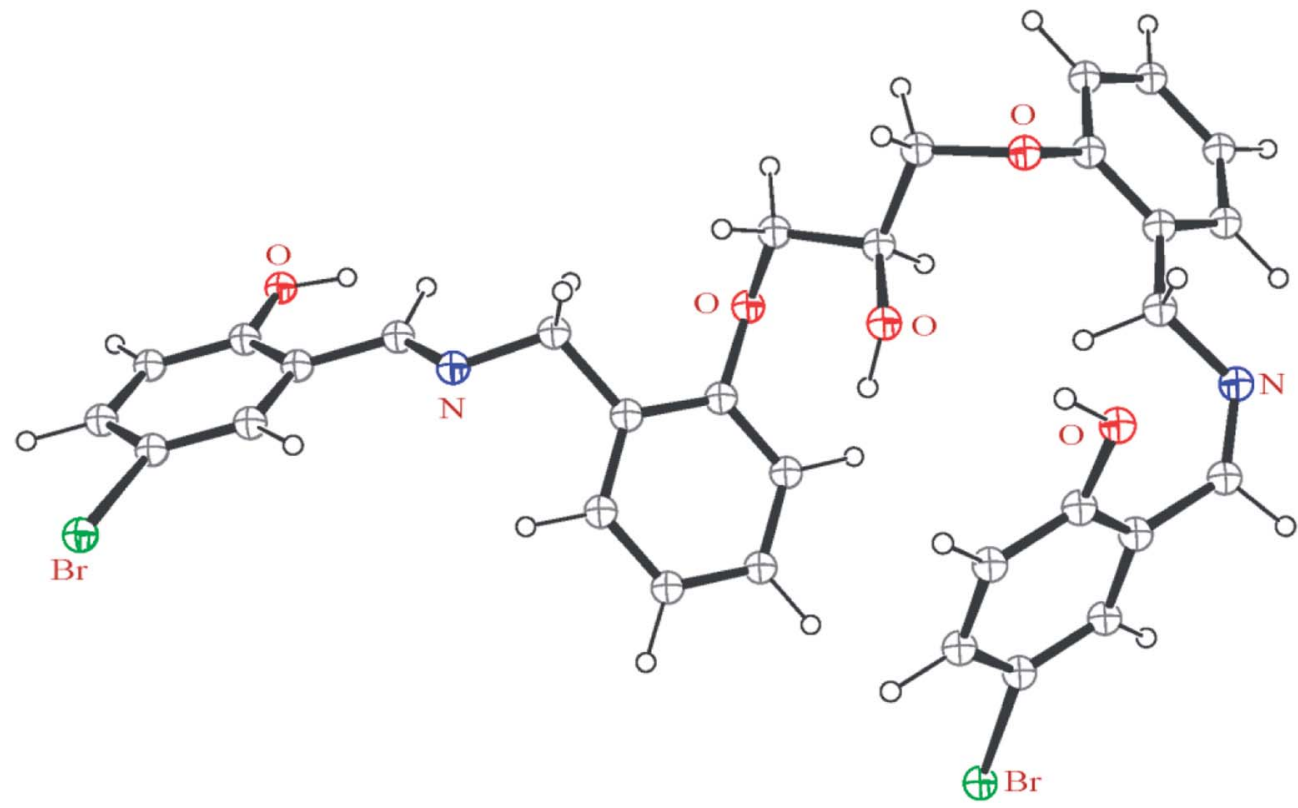

Fig. 10 Optimized structure of the $\mathrm{H}_{3} \mathrm{~L}^{\mathrm{Br}}$ ligand.

Table 7 The calculated fitness values for the complexes 1-3 and $\mathrm{H}_{3} \mathrm{~L}^{\mathrm{Br}}$

\begin{tabular}{lllllrrrrr}
\hline & BRAF-kinase & CatB & DNA-gyrase & HDAC7 & rHA & RNR & TrxR & TS & Top II \\
\hline $\mathrm{H}_{3} \mathrm{~L}^{\mathrm{Br}}$ & 70.96 & 50.46 & 62.70 & 78.53 & 71.85 & 60.63 & 84.75 & 73.37 & 75.66 \\
$\mathrm{H}_{3} \mathrm{~L}^{\text {NO2 }}$ & 68.99 & 50.14 & 54.82 & 70.64 & 70.40 & 68.56 & 83.28 & 76.29 & 71.07 \\
Complex 1 & 34.52 & 27.07 & 44.94 & 28.77 & 27.44 & 39.93 & 15.21 & 58.54 & 53.01 \\
Complex 2 & 59.63 & 35.38 & 17.23 & 44.31 & 6.76 & 42.29 & 54.29 & 62.61 & 24.13 \\
Complex 3 & 33.99 & 32.74 & 29.81 & 9.54 & 33.34 & 34.14 & 0.00 & 55.23 & 45.03
\end{tabular}

presented in Scheme 2(a)) is tetrahedral geometry (56\%, Fig. 3) as observed in $\mathbf{1}$. The Co-O and Co-N bond lengths average in 1 (1.917 and $1.985 \AA$, respectively) are slightly longer than the CSD average (1.877 and $1.940 \AA$ for the Co-O and Co-N, respectively, Scheme 2).

In the structure of the complex, the ligand is tetradentate and forms two six-membered and one 14-membered chelate ring. The formation of a 14-membered chelate ring around the cobalt atom is very rare and there is only one example among the CSD complexes (in this search, the 14-membered chelate ring formed by macrocyclic ligands were omitted).$^{68}$ One sixmembered chelate ring is planar (with rms value of $0.033 \AA$ for the $\mathrm{N}_{2}$ atom) while another is the non-planar (with rms value of $0.139 \AA$ for the Co1 atom). The difference between planarity of the chelate rings can be attributed to the coordinated bond angles of these rings.

3.2.2 Crystal structures of $\left[\mathrm{Cu}_{2}\left(\mathrm{~L}^{\mathrm{Br}}\right)(\mu-1,3-\mathrm{OAc})\right] \cdot \mathrm{MeOH}(2)$. In the binuclear structure of 2 (Fig. 4 ), each copper atom has $\mathrm{CuNO}_{4}$ environment and is coordinated by one oxygen atom of the acetato ligand, one oxygen atom of the deprotonated phenol moiety, one oxygen atom of the ether group and one oxygen atom of the deprotonated alcoholic group of the ligand along with the one nitrogen atom of the imine site with coordination number of five. A penta-coordinate geometry of 2 , may adopt either a square pyramidal or a trigonal bipyramidal structure which is determined by applying the formula of Addison et $a l .{ }^{67,69}$ The angular structural parameter, $\tau(\tau=(\beta-\alpha) / 60$, where $\alpha$ and $\beta$ are the two largest angles at the copper atom with $\beta \geq \alpha$ ), was calculated to be 0.07 and 0.39 , respectively for $\mathrm{Cu} 1$ and $\mathrm{Cu} 2$ atoms indicating a distorted square-pyramidal geometry. Among the four $\mathrm{Cu}-\mathrm{O}$ bond lengths, the $\mathrm{Cu}-\mathrm{O}^{\text {Ether }}$ bond length is longer than the other bonds.

In the crystal structures of the 2 , one acetate ligand acts as bridge between two copper atoms. For comparing the coordination mode of the acetato ligand in 2 with CSD analogues, a structural survey was carried out and results presented in Table 4. These data reveal that eight different coordination modes have been reported for copper complexes containing the acetato ligand. Among these coordination modes, the "O;O" mode (Table 4 ) is the most observed ones (48\%, Fig. 5) in which the acetato unit acts as $\mathrm{O}_{2}$-donor and bridges two metal centers. This coordination mode also observed in the 2 . The monodentate mode of "O" is the second most common among the CSD analogues $(27 \%$, Fig. 5). In another comparison, the percentage of bridged and non-bridged structures was calculated. These data revealed that the acetato unit commonly forms a bridged structure (59\%) with copper atoms. In most cases this ligand is coordinated toward copper atom without forming the chelate ring (84\%). 


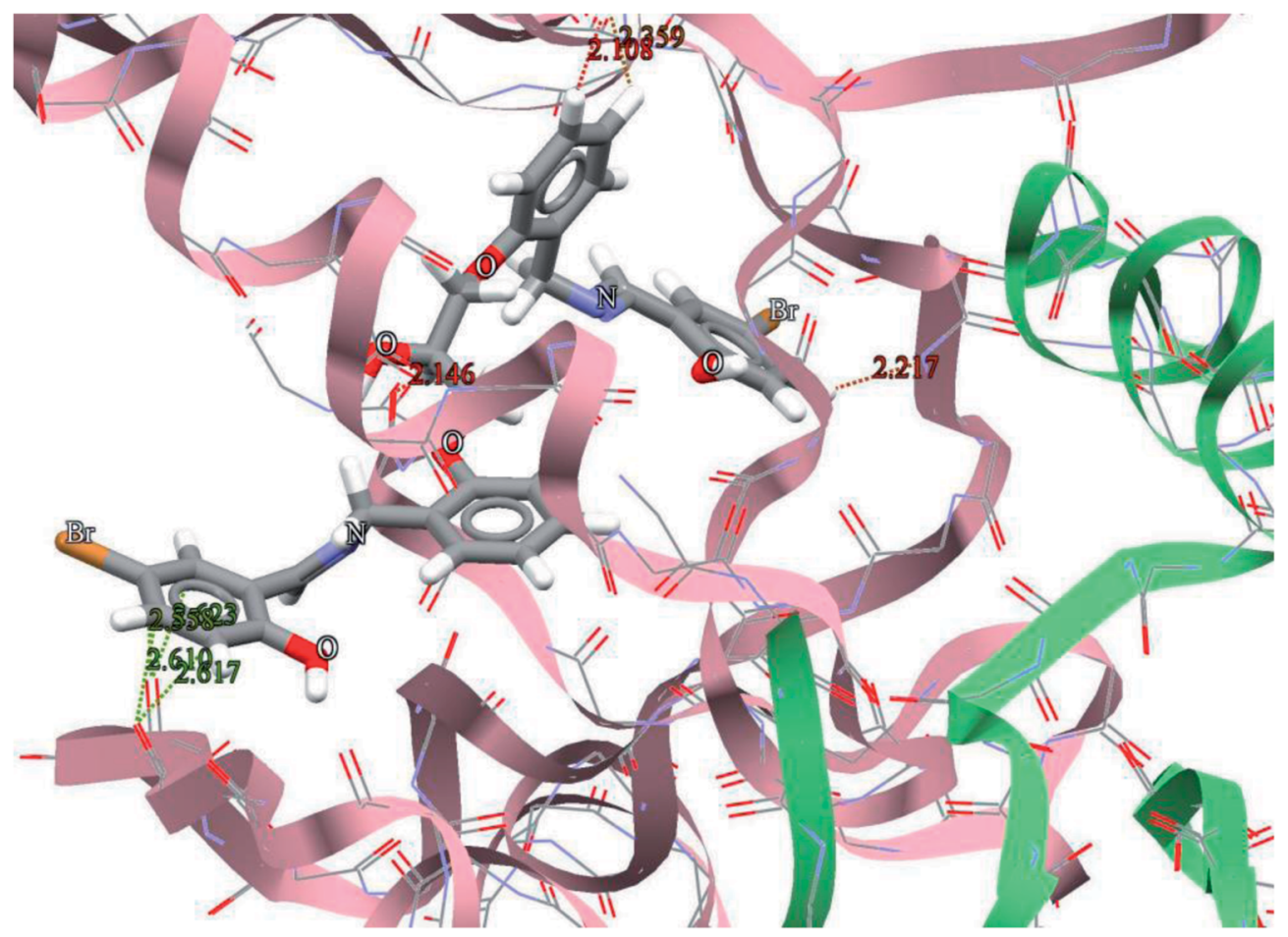

Fig. 11 Docking study results, showing the interaction between $\mathrm{H}_{3} \mathrm{~L}^{\mathrm{Br}}$ and $\mathrm{BRAF}$ kinase protein.

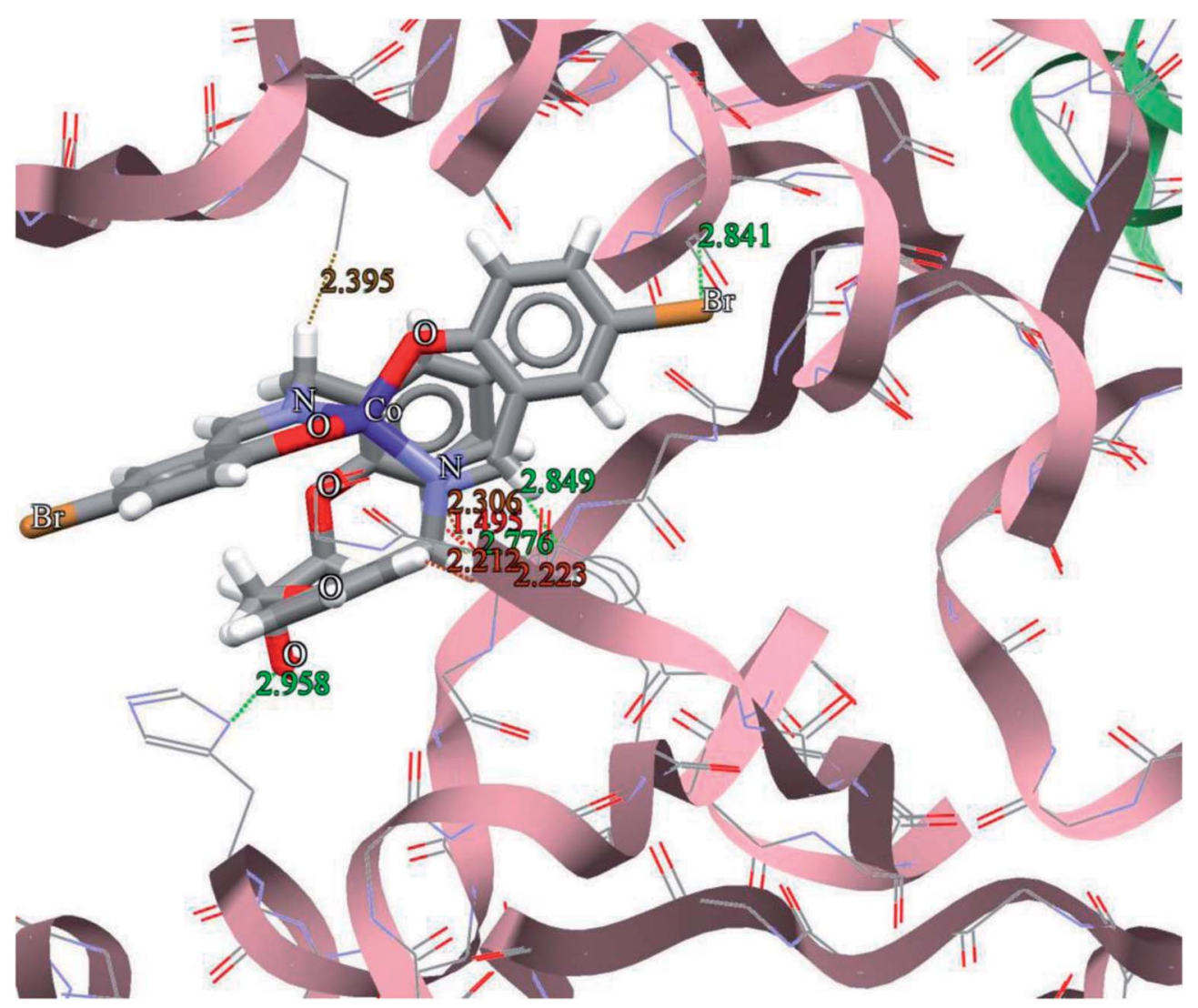

Fig. 12 Docking study results, showing the interaction between complex 1 and BRAF kinase protein. 
Table 8 Concentrations of ligands $\left(\mathrm{H}_{3} \mathrm{~L}^{\mathrm{NO} 2}\right.$ and $\left.\mathrm{H}_{3} \mathrm{~L}^{\mathrm{Br}}\right)$ and their complexes 1-3 that induced a $50 \%$ decrease in $\mathrm{K} 562$ cell survival (expressed as $I_{50}\left(\mu \mathrm{g} \mathrm{mL}{ }^{-1}\right)$ ). The compounds were incubated with cells for 24,48 and $72 \mathrm{~h}$. $\mathrm{IC}_{50}$ values are expressed as the mean $\pm \mathrm{SD}$ determined from three independent experiments

\begin{tabular}{llll}
\hline Compounds & $24 \mathrm{~h}$ & $48 \mathrm{~h}$ & $72 \mathrm{~h}$ \\
\hline $\mathrm{H}_{3} \mathrm{~L}^{\mathrm{Br}}$ & $22.00 \pm 0.51$ & $22.03 \pm 0.43$ & $21.87 \pm 0.21$ \\
Complex 1 & $11.56 \pm 0.13$ & $10.71 \pm 0.26$ & $11.52 \pm 0.10$ \\
Complex 2 & $13.92 \pm 0.42$ & $13.17 \pm 0.50$ & $13.35 \pm 0.32$ \\
Complex 3 & $14.58 \pm 0.33$ & $15.67 \pm 0.37$ & $16.36 \pm 0.32$ \\
\hline
\end{tabular}

The $\mathrm{H}_{3} \mathrm{~L}^{\mathrm{Br}}$ ligand precursor is triply deprotonated and heptadentate and form four six-membered and two five-membered chelate rings. The deprotonated alcoholic moiety of ligands is bridging two copper atoms.

3.2.3 Crystal structures of $\left[\mathrm{Zn}\left(\mathrm{HL}^{\mathrm{Br}}\right)\right]$ (3). X-ray analysis of the complex 3 (Fig. 6), reveals that $\mathrm{ZnN}_{2} \mathrm{O}_{2}$ environment for zinc atom and coordination number of four. In these structures, the $\tau_{\text {sq }}$ value is calculated to be 0.33 for 3 , indicating a tetrahedral geometry (Fig. 6 and 7). The CSD database reveals that the common geometry between analogues of the complex 3 (with base presented in Scheme 2(b)), is tetrahedral geometry (Fig. 8) which is the expected geometry for $\mathrm{d}^{10}$ complexes. The $\mathrm{Zn}-\mathrm{N}$ and $\mathrm{Zn}-\mathrm{O}$ bond lengths average in complex 3 (2.000 and 1.929 A, respectively) are comparable with the CSD average (Scheme $2(\mathrm{~b}))$.

In this complex, the ligand acts as tetradentate and forms two six-membered and one 14-membered chelate ring. The formation of 14-membered chelate ring around the zinc atom is very rare and there is only one example for such structure ${ }^{70}$ (in this search, the 14-memberd chelate ring formed by macrocyclic ligands were omitted). One six-membered chelate ring is planar (with rms value of $0.027 \AA$ for the $\mathrm{C} 4$ and C28 atoms) while another is the non-planar (with rms value of $0.139 \AA$ for the Zn1 atom).

3.2.4 Crystal network interactions. In the crystal network of the compounds (Fig. 2 and 7) intermolecular $\mathrm{C}-\mathrm{H} \cdots \mathrm{O}$ and $\mathrm{O}-\mathrm{H} \cdots \mathrm{O}$ (except 3) hydrogen bonds link adjacent complexes. In this way the oxygen atoms participate in hydrogen bonding as proton donors and acceptors at the same time while the carbon atoms participate as proton donors.

In addition to the hydrogen bonds, the crystal networks of the compounds $(\mathbf{1}, \mathbf{3})$ are further stabilized by inter and intra molecular $\pi-\pi$ stacking interactions (Table 5) between aromatic rings $\mathrm{s}^{71,72}$ (Fig. 2 and 7). $\mathrm{H}_{3} \mathrm{~L}^{\mathrm{Br}}$ ligand has two arms and each arm contains one terminal and one middle aromatic ring. In 1 and 3 the arms of ligand are twisted to form $\pi-\pi$ stacking interactions between the terminal phenyl of one arm with the middle aromatic group on the other arm. The formation of these types of the intra molecular $\pi-\pi$ stacking interactions may be affecting the coordination geometry in these ligands.

Total intermolecular interaction energy for one molecule of the complexes 1-3 were calculated using Mercury ${ }^{73}$ and its CSD-materials tool. ${ }^{62,74}$ For this, the sum of the intermolecular interactions energy in a molecular packing shell containing
100 molecules $^{75}$ around the one molecule of 1-3 were calculated to be $-390.23,-561.05$ (complex 2), -44.96 ( $\mathrm{MeOH}$ in the 2) and $-420.68 \mathrm{~kJ} \mathrm{~mol}^{-1}$ (Fig. 9), respectively, confirming that 2 is more stabilized in the solid state by its network interactions than the others. ${ }^{75}$ Also comparing the energy level of interactions for one molecule of 2 with the trapped methanol molecule in the crystal network of 2 showed that one molecule of $\mathbf{2}$ is more stabilized than the methanol molecule by inter molecular interactions. In 1, 89\% of the total energy equates to the interactions with its fourteen closest neighboring molecules in ranges of 7.147-13.965 $\AA$ distances (Fig. 9). This value for the same condition for complexes 2 and 3 is 65 (complex 2), 96 (MeOH in the complex 2) and $89 \%$.

\subsection{Theoretical studies}

To study the charge distribution before and after complexation, an NBO analysis was done on the free $\mathrm{H}_{3} \mathrm{~L}^{\mathrm{Br}}$ ligand and its copper and zinc complexes (Table 6). For this study all structures were optimized before NBO analysis (Fig. 10, $\mathrm{H}_{3} \mathrm{~L}^{\mathrm{Br}}$ ). The results reveal that the calculated charge on the metal atom (+0.91 and +1.45 for copper and zinc atoms, respectively) is lower than the formal charge $(+2)$ owing to the electron donation of ligand during the complexation. The charge on the copper atom is decreased more than the zinc atom which can be attributed to the three step deprotonation $\left(\mathrm{L}^{3-}\right)$ of the ligand in coordination toward copper atom while in zinc complex the ligand act as $\mathrm{HL}^{2-}$. Also the total charge on the acetato ligand is calculated to be -0.58 for 2 , showing the electron donation of this ligand to the copper atom and may be another reason for the lower charge on the copper compared to the zinc atom. Based on the calculated total charge values, the charge of the carbon atoms of complexes is more positive than that of the free ligand, whilst the total charge of the hydrogen and nitrogen atoms is more negative than respect to the free ligands. This observation reveals that the carbon atoms play an important role in electron donation toward metal atom and decreasing the charge of them.

In the structures of the optimized $2^{\text {opt }}, \tau$ was calculated to be 0.08 , indicating a square-pyramidal geometry with negligible distortion respect to the solid state result. Similarly to the X-ray results, the $\mathrm{Cu}-\mathrm{O}^{\text {Ether }}$ bond length is longer than the other bonds. For the optimized structure of the $3^{\text {opt }}$, the $\tau_{\text {sq }}$ value is calculated to be 0.34 , indicating an incline to a tetrahedral geometry similarly to the solid state result.

\subsection{Docking studies}

For predicting and comparison the biological activates of the ligand and complexes, interactions of these compounds with nine macromolecule receptors using Gold ${ }^{63}$ docking software was studied. The Gold docking results are reported in terms of the values of fitness which means the higher the fitness the better the docked interaction of the compounds. ${ }^{53}$ The results of the docking presented in this work is the best binding results out of the favorably ten predicted by Gold.

The general features from the Gold docking prediction (Table 7) show that all studied structures can be consider as 
Table 9 Morphological changes of $\mathrm{K} 562$ cells after $48 \mathrm{~h}$ treatment with $\mathrm{IC} \mathrm{C}_{50}$ concentrations of $\mathrm{H}_{3} \mathrm{~L}^{\mathrm{Br}}$ and complexes $1-3$. The cells were stained with acridine orange and propidium iodide and examined by fluorescence microscope. The presence of early and late apoptosis along with the necrosis of $\mathrm{K} 562$ cells could be seen. (a) $\mathrm{H}_{3} \mathrm{~L}^{\mathrm{Br}}$, (b) complex 1, (c) complex 2, (d) complex 3

Column graph $\quad$ Normal cells $\quad$ Cells after exposure to compounds
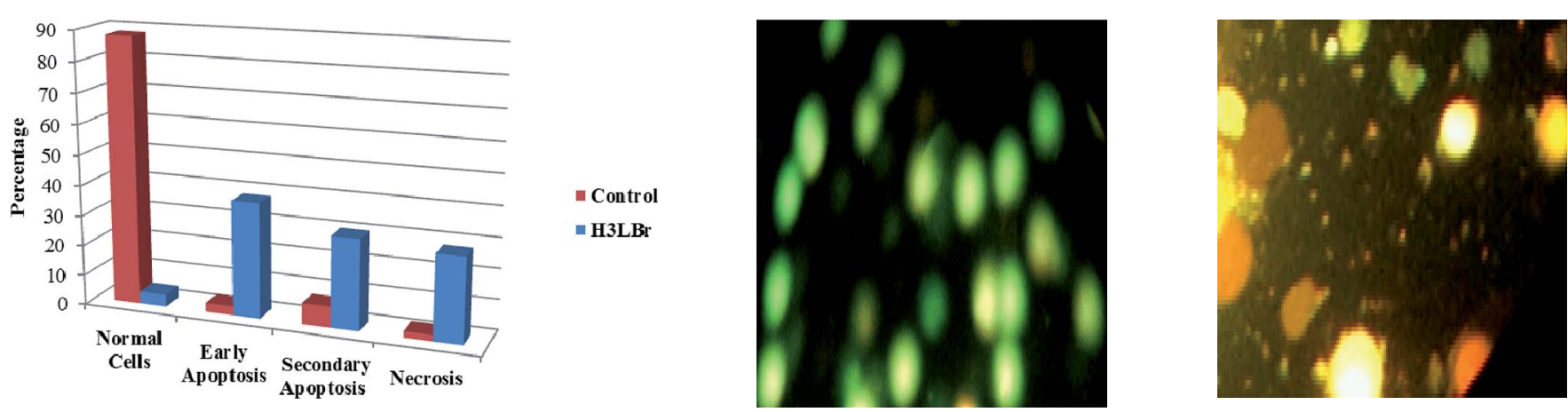

(a)
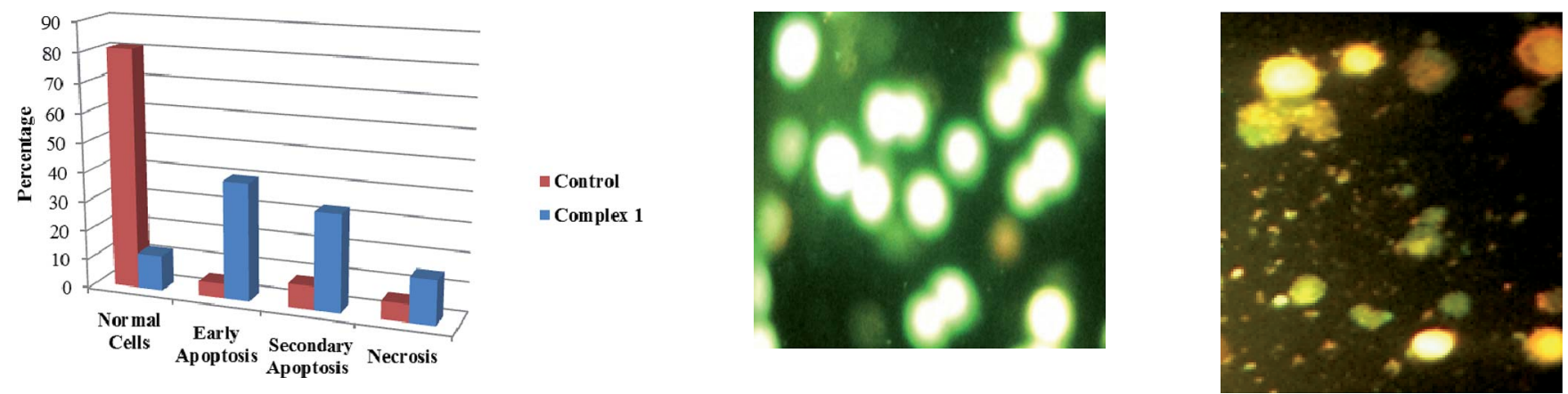

(b)

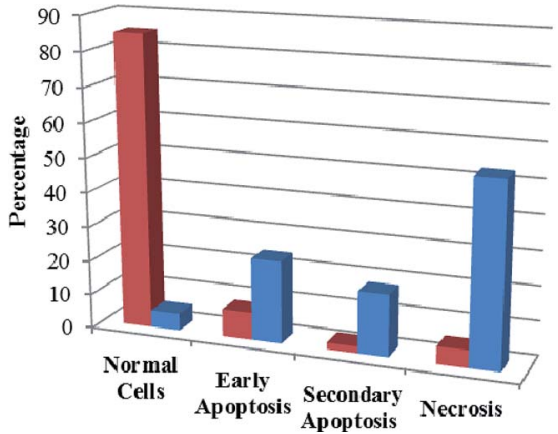

$\because$ Control

- Complex 1

(c)

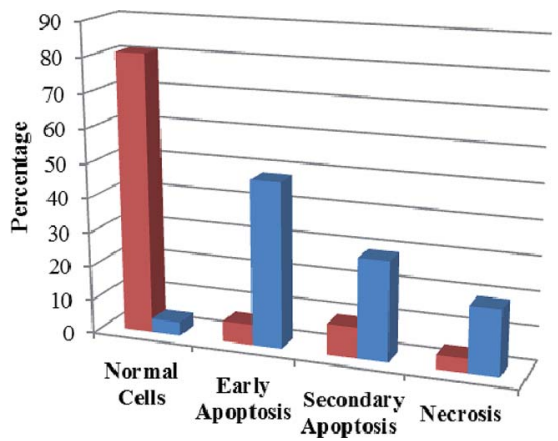

- Control

-Complex 2
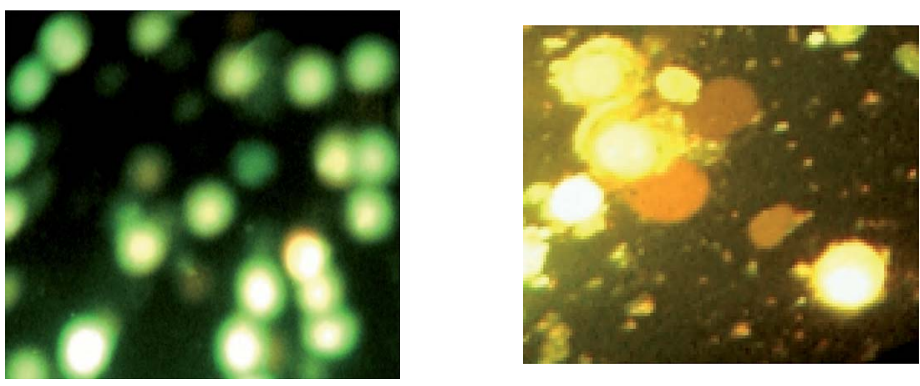

- Control

- Complex 3
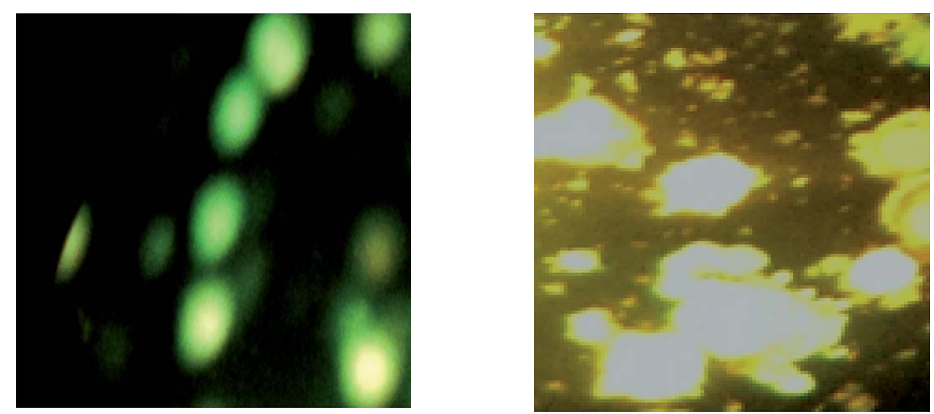

(d) 
biologically active compounds. The best predicted target for the $\mathrm{H}_{3} \mathrm{~L}^{\mathrm{Br}}$ is TrxR, while for the complexes is TS. The docking result of the interaction between $\mathrm{H}_{3} \mathrm{~L}^{\mathrm{Br}}$ and complex 1 with BRAF kinase protein is shown in the Fig. 11 and 12, respectively.

\subsection{Biological screening}

We evaluated the in vitro cytotoxicity of $\mathrm{H}_{3} \mathrm{~L}^{\mathrm{Br}}$ ligand and its complexes with cobalt, copper and zinc on the human cancer cell line K562. Results are expressed as the $\mathrm{IC}_{50}$ values and are summarized in Table 8. The MTT assay showed that tested compounds exerted significant cytotoxic effects against $\mathrm{K} 562$ cell lines. For the studied compounds, the cytotoxic effects of the complexes are higher than the free ligand; showing that the biologically activities of these ligands are increased by binding to a metal center. The order of the cytotoxicity activity for different metal centers is $\mathrm{Co}>\mathrm{Cu}>\mathrm{Zn}$.

We also investigated the type of cell death induced by compounds in K562 cells, based on the analysis of morphological characteristics of the cells after the double staining of cells with acridine orange (AO) and propidium iodide (PI) by fluorescence microscopy. Morphological features of apoptosis such as chromatin condensation, nuclear fragmentation and alterations in the size and the shape of cells were observed after $48 \mathrm{~h}$ treatment with $\mathrm{IC}_{50}$ concentrations of the compounds. Also, the features of late apoptosis were clearly expressed; the DNA was fragmented and stained orange and red. As shown in Table 9, the percentage of early apoptotic cells after treatment with complex 3 for $48 \mathrm{~h}$ is higher than the other compounds (48\%). Among the four tested compounds, the ability of complexes 1 and 2 to induce secondary apoptosis (33\%) and necrosis (53\%) in K562 cells is significant.

\section{Conclusion}

Four compartmental Schiff compounds, 2,2'-((c(((2-hydroxypropane1,3-diyl)bis(oxy))bis(2,1-phenylene))bis(methylene))bis(azanylylidene)) bis(methanylylidene))bis(4-bromophenol) $\left(\mathrm{H}_{3} \mathrm{~L}^{\mathrm{Br}}\right), \quad\left[\mathrm{Co}\left(\mathrm{HL}^{\mathrm{Br}}\right)\right] \quad(\mathbf{1})$, $\left[\mathrm{Cu}_{2}\left(\mathrm{~L}^{\mathrm{Br}}\right)(\mu-1,3-\mathrm{OAc})\right] \cdot \mathrm{MeOH}(2),\left[\mathrm{Zn}\left(\mathrm{HL}^{\mathrm{Br}}\right)\right]$ (3), were prepared, their spectral (IR, ${ }^{1} \mathrm{H}$ NMR) and structural (single crystal X-ray diffraction) properties were investigated. In the complexes of $\mathbf{1}$ and $\mathbf{3}$, the metal atom has tetrahedral geometry. The ligand molecule in theses structure forms two six-membered and one 14-membered chelate rings which is very rare among the CSD database. In the complex of 2 the copper atom has a square pyramidal geometry. In this structure, $\mathrm{HL}^{\mathrm{Br}}$ and acetato ligands bridge two copper atoms to form a binuclear structure. Among the different coordination modes of the acetate ligand which is coordinated to the copper atom, the " $\mathrm{O} ; \mathrm{O}$ " mode is the most observed ones (48\%) which is observed mode in 2 . Based on these data, the acetato ligand commonly forms a bridged (59\%) and non-chelated (84\%) structures with copper atom.

In addition to the hydrogen bonds in the crystal network of the complexes, there are $\pi-\pi$ stacking interactions between aromatic rings, showing the high ability of these molecules to interact with neighboring units and making them good choice to docking studies. The docking studies on the eight synthesized compounds revealed that these compounds might be biologically active by interacting with the nine biomacromolecules (BRAF kinase, CatB, DNA gyrase, HDAC7, rHA, RNR, TrxR, TS and Top II). The best predicted targets for the free ligand is TrxR, while for the complexes is TS. The biological assay of the compounds on the human cancer cell line K562 confirmed the docking results. For the studied compounds, the cytotoxic effects of the complexes are higher than the free ligand with order of the cytotoxicity activity $\mathrm{Co}>\mathrm{Cu}>\mathrm{Zn}$. Among the compounds, the complexes 1-3 can induce the secondary apoptosis (33\%), necrosis (53\%) and early apoptosis (48\%) in K562 cells better than the others, respectively. The NBO analysis of the compounds revealed that among the hydrogen, carbon, nitrogen and oxygen atoms of the coordinated ligand, the carbon atoms act as electron donor and decrease the charge of the metal atom.

\section{Conflicts of interest}

There are no conflicts to declare.

\section{Acknowledgements}

This study has been supported by the Council of the Payame Noor University, Iran. The authors thank Prof. Dr K. Adil from Universite du Maine, Institut des Molecules et Materiaux du Mans, Le Mans Cedex, France for the X-ray crystallography data collection.

\section{References}

1 K. C. Gupta and A. K. Sutar, Coord. Chem. Rev., 2008, 252, 1420-1450.

2 R. Kannappan, M. Matsumoto, J. Hallren and K. M. Nicholas, J. Mol. Catal. A: Chem., 2011, 339, 72-78.

3 L.-H. Li, W.-K. Dong, Y. Zhang, S. F. Akogun and L. Xu, Appl. Organomet. Chem., 2017, 31, e3818.

4 A. Wesley Jeevadason, K. Kalidasa Murugavel and M. A. Neelakantan, Renewable Sustainable Energy Rev., 2014, 36, 220-227.

5 W.-K. Dong, X.-L. Li, L. Wang, Y. Zhang and Y.-J. Ding, Sens. Actuators, 2016, B229, 370-378.

6 B.-J. Wang, W.-K. Dong, Y. Zhang and S. F. Akogun, Sens. Actuators, 2017, B247, 254-264.

7 I. Ahamad, R. Prasad and M. A. Quraishi, Corros. Sci., 2010, 52, 933-942.

8 C.-M. Che, S.-C. Chan, H.-F. Xiang, M. C. W. Chan, Y. Liu and Y. Wang, Chem. Commun., 2004, 1484-1485.

9 M. Zhang, D.-M. Xian, H.-H. Li, J.-C. Zhang and Z.-L. You, Aust. J. Chem., 2012, 65, 343-350.

10 M. D. Altıntop, A. Özdemir, G. Turan-Zitouni, S. Ilgın, Ö. Atlı, G. İşcan and Z. A. Kaplancıklı, Eur. J. Med. Chem., 2012, 58, 299-307.

11 V. C. da Silveira, J. S. Luz, C. C. Oliveira, I. Graziani, M. R. Ciriolo and A. M. d. C. Ferreira, J. Inorg. Biochem., 2008, 102, 1090-1103.

12 K. Shanker, R. Rohini, V. Ravinder, P. M. Reddy and Y.-P. Ho, Spectrochim. Acta, Part A, 2009, 73, 205-211. 
13 Y. Li and Z.-y. Yang, Inorg. Chim. Acta, 2009, 362, 4823-4831. 14 M. Taha, N. H. Ismail, M. S. Baharudin, S. Lalani, S. Mehboob, K. M. Khan, S. yousuf, S. Siddiqui, F. Rahim and M. I. Choudhary, Med. Chem. Res., 2015, 24, 1310-1324.

15 C. Jing, C. Wang, K. Yan, K. Zhao, G. Sheng, D. Qu, F. Niu, H. Zhu and Z. You, Bioorg. Med. Chem., 2016, 24, 270-276.

16 J. R. Morrow and K. A. Kolasa, Inorg. Chim. Acta, 1992, 195, 245-248.

17 A. D. Tiwari, A. K. Mishra, S. B. Mishra, B. B. Mamba, B. Maji and S. Bhattacharya, Spectrochim. Acta, Part A, 2011, 79, 1050-1056.

18 A. Biswas, S. Mondal and S. Mohanta, J. Coord. Chem., 2013, 66, 152-170.

19 P. Chakraborty and S. Mohanta, Polyhedron, 2015, 87, 98108.

20 A. Jana, K. Das, S. Konar, A. Dhara, S. Biswas, S. Chatterjee and T. K. Mondal, J. Mol. Struct., 2015, 1100, 318-327.

21 P. Chakraborty, I. Majumder, H. Kara, S. K. Chattopadhyay, E. Zangrando and D. Das, Inorg. Chim. Acta, 2015, 436, 139145.

22 P. A. Vigato, V. Peruzzo and S. Tamburini, Coord. Chem. Rev., 2012, 256, 953-1114.

23 F. Benetollo, P. Di Bernardo, S. Tamburini, P. A. Vigato and P. Zanonato, Inorg. Chem. Commun., 2008, 11, 246-251.

24 L. Chen, W.-K. Dong, H. Zhang, Y. Zhang and Y.-X. Sun, Cryst. Growth Des., 2017, 17, 3636-3648.

25 W.-K. Dong, J.-C. Ma, L.-C. Zhu and Y. Zhang, New J. Chem., 2016, 40, 6998-7010.

26 S. A. Sadeek, M. S. El-Attar and S. M. Abd El-Hamid, J. Mol. Struct., 2013, 1051, 30-40.

27 D. E. Fenton, Inorg. Chem. Commun., 2002, 5, 537-547.

28 F. Benetollo, V. Peruzzo, S. Tamburini and P. A. Vigato, Inorg. Chem. Commun., 2012, 15, 84-87.

29 D. E. Fenton and H. Okawa, Chem. Ber., 1997, 130, 433-442.

30 A. Jayamani, M. Sethupathi, S. O. Ojwach and N. Sengottuvelan, Inorg. Chem. Commun., 2017, 84, 144-149.

31 E. Lodyga-Chruscinska, M. Symonowicz, A. Sykula, A. Bujacz, E. Garribba, M. Rowinska-Zyrek, S. Oldziej, E. Klewicka, M. Janicka, K. Krolewska, M. Cieslak, K. Brodowska and L. Chruscinski, J. Inorg. Biochem., 2015, 143, 34-47.

32 N. Nanjundan, R. Narayanasamy, S. Geib, K. Velmurugan, R. Nandhakumar, M. D. Balakumaran and P. T. Kalaichelvan, Polyhedron, 2016, 110, 203-220.

33 A. Banerjee, A. Guha, J. Adhikary, A. Khan, K. Manna, S. Dey, E. Zangrando and D. Das, Polyhedron, 2013, 60, 102-109.

34 R. Sanyal, S. K. Dash, P. Kundu, D. Mandal, S. Roy and D. Das, Inorg. Chim. Acta, 2016, 453, 394-401.

35 A. K. Abu Al-Nasr and R. M. Ramadan, Spectrochim. Acta, 2013, A105, 14-19.

36 V. R. Martínez, M. V. Aguirre, J. S. Todaro, O. E. Piro, G. A. Echeverría, E. G. Ferrer and P. A. M. Williams, Toxicol. In Vitro, 2018, 48, 205-220.

37 A. Adhikari, N. Kumari, M. Adhikari, N. Kumar, A. K. Tiwari, A. Shukla, A. K. Mishra and A. Datta, Bioorg. Med. Chem., 2017, 25, 3483-3490.

38 L.-Y. Tu, J. Pi, H. Jin, J.-Y. Cai and S.-P. Deng, Bioorg. Med. Chem. Lett., 2016, 26, 2730-2734.
39 J. Dam, Z. Ismail, T. Kurebwa, N. Gangat, L. Harmse, H. M. Marques, A. Lemmerer, M. L. Bode and C. B. de Koning, Eur. J. Med. Chem., 2017, 126, 353-368.

40 D. Palanimuthu and A. G. Samuelson, Inorg. Chim. Acta, 2013, 408, 152-161.

41 A. K. Renfrew, E. S. O'Neill, T. W. Hambley and E. J. New, Coord. Chem. Rev., 2017, 221-233.

42 P. Nithya, R. Rajamanikandan, J. Simpson, M. Ilanchelian and S. Govindarajan, Polyhedron, 2018, 145, 200-217.

43 F. A. Al-Saif, K. A. Alibrahim, J. A. Alfurhood and M. S. Refat, J. Mol. Liq., 2018, 249, 438-453.

44 S. R. Morcelli, É. S. Bull, W. S. Terra, R. O. Moreira, F. V. Borges, M. M. Kanashiro, A. J. Bortoluzzi, L. L. F. Maciel, J. C. de A. Almeida, A. H. Júnior and C. Fernandes, J. Inorg. Biochem., 2016, 161, 73-82.

45 A. K. El-Sawaf, F. El-Essawy, A. A. Nassar and E.-S. A. ElSamanody, J. Mol. Struct., 2018, 1157, 381-394.

46 M. Jopp, J. Becker, S. Becker, A. Miska, V. Gandin, C. Marzano and S. Schindler, Eur. J. Med. Chem., 2017, 132, 274-281.

47 N. Sanz del Olmo, M. Maroto-Díaz, R. Gómez, P. Ortega, M. Cangiotti, M. F. Ottaviani and F. J. de la Mata, J. Inorg. Biochem., 2017, 177, 211-218.

48 C. Acilan, B. Cevatemre, Z. Adiguzel, D. Karakas, E. Ulukaya, N. Ribeiro, I. Correia and J. C. Pessoa, Data Brief, 2016, 9, 1160-1174.

49 S. S. Massoud, F. R. Louka, G. T. Ducharme, R. C. Fischer, F. A. Mautner, J. Vančo, R. Herchel, Z. Dvořák and Z. Trávníček, J. Inorg. Biochem., 2018, 180, 39-46.

50 J. Qi, S. Liang, Y. Gou, Z. Zhang, Z. Zhou, F. Yang and H. Liang, Eur. J. Med. Chem., 2015, 96, 360-368.

51 F. Marandi, K. Moeini, F. Alizadeh, Z. Mardani, C. K. Quah, W.-S. Loh and J. D. Woollins, Inorg. Chim. Acta, 2018, 482, 717-725.

52 F. Marandi, K. Moeini, F. Alizadeh, Z. Mardani, K. Quah Ching and W.-S. Loh, Z. Naturforsch., 2018, 73b, 369.

53 A. A. Adeniyi and P. A. Ajibade, Molecules, 2013, 18, 37603778.

54 H. G. Drexler, The Leukemia-Lymphoma Cell Line Facts Book, Academic Press, London, 2001.

55 S. A. Hosseini-Yazdi, P. Samadzadeh-Aghdam, A. Mirzaahmadi, A. A. Khandar, G. Mahmoudi, M. Ruck, T. Doert, S. S. Balula and L. Cunha-Silva, Polyhedron, 2014, 80, 41-46.

56 G. Sheldrick, Acta Crystallogr., 2008, A64, 112-122.

57 L. J. Farrugia, J. Appl. Crystallogr., 1997, 30, 565.

58 M. N. Burnett and C. K. Johnson, Ortep-III, Report ORNL6895, Oak Ridge National Laboratory, Oak Ridge, Tennessee, U.S., 1996.

59 G. Bergerhof, M. Berndt and K. Brandenburg, J. Res. Natl. Inst. Stand. Technol., 1996, 101, 221-225.

60 M. J. Frisch, G. W. Trucks, H. B. Schlegel, G. E. Scuseria, M. A. Robb, J. R. Cheeseman, G. Scalmani, V. Barone, B. Mennucci, G. A. Petersson, H. Nakatsuji, M. Caricato, X. Li, H. P. Hratchian, A. F. Izmaylov, J. Bloino, G. Zheng, J. L. Sonnenberg, M. Hada, M. Ehara, K. Toyota, R. Fukuda, J. Hasegawa, M. Ishida, T. Nakajima, Y. Honda, 
O. Kitao, H. Nakai, T. Vreven, J. A. Montgomery Jr., J. E. Peralta, F. Ogliaro, M. J. Bearpark, J. Heyd, E. N. Brothers, K. N. Kudin, V. N. Staroverov, R. Kobayashi, J. Normand, K. Raghavachari, A. P. Rendell, J. C. Burant, S. S. Iyengar, J. Tomasi, M. Cossi, N. Rega, N. J. Millam, M. Klene, J. E. Knox, J. B. Cross, V. Bakken, C. Adamo, J. Jaramillo, R. Gomperts, R. E. Stratmann, O. Yazyev, A. J. Austin, R. Cammi, C. Pomelli, J. W. Ochterski, R. L. Martin, K. Morokuma, V. G. Zakrzewski, G. A. Voth, P. Salvador, J. J. Dannenberg, S. Dapprich, A. D. Daniels, Ö. Farkas, J. B. Foresman, J. V. Ortiz, J. Cioslowski and D. J. Fox, Gaussian, Inc., Wallingford, CT, USA, 2009.

61 J. P. Perdew, Phys. Rev., 1986, B33, 8822-8824.

62 A. Gavezzotti, Acc. Chem. Res., 1994, 27, 309-314.

63 G. Jones, P. Willett, R. C. Glen, A. R. Leach and R. Taylor, J. Mol. Biol., 1997, 267, 727-748.

64 K. Nakamoto, in Infrared and raman spectra of inorganic and coordination compounds, John Wiley, Hoboken, ed. 6, 2009, p. 232 .

65 M. Hakimi, K. Moeini, Z. Mardani and F. Khorrami, J. Korean Chem. Soc., 2013, 57, 352-356.

66 B. Żurowska, J. Mroziński and K. Ślepokura, Polyhedron, 2007, 26, 3379-3387.
67 M. Hakimi, Z. Mardani, K. Moeini and F. Mohr, Polyhedron, 2015, 102, 569-577.

68 H. Zhang, W. Jiang, J. Yang, Y.-Y. Liu, S. Song and J.-F. Ma, CrystEngComm, 2014, 16, 9939-9946.

69 A. W. Addison, T. Rao, J. Reedjik, J. V. Rijn and G. Verschoor, Dalton Trans., 1984, 1349.

70 B. Nath, D. Kalita and J. B. Baruah, J. Coord. Chem., 2011, 64, 2545-2553.

71 F. Marandi, K. Moeini, B. Mostafazadeh and H. Krautscheid, Polyhedron, 2017, 133, 146-154.

72 F. Marandi, K. Moeini, S. Ghasemzadeh, Z. Mardani, C. K. Quah and W.-S. Loh, J. Mol. Struct., 2017, 1149, 92-98.

73 C. F. Macrae, I. J. Bruno, J. A. Chisholm, P. R. Edgington, P. McCabe, E. Pidcock, L. Rodriguez-Monge, R. Taylor, J. Van De Streek and P. A. Wood, J. Appl. Crystallogr., 2008, 41, 466-470.

74 A. Gavezzotti and G. Filippini, J. Phys. Chem., 1994, 98, 48314837.

75 Z. Mardani, V. Golsanamlou, S. Khodavandegar, K. Moeini, A. M. Z. Slawin and J. D. Woollins, J. Coord. Chem., 2018, $1-15$. 